\title{
HUDOBNÁ TOPOGRAFIA SPIŠA V KONTEXTE VÝSKUMU MIEST V RANOM NOVOVEKU
}

\author{
JANKa Petőczová
}

\section{Abstract}

The aim of this study is to demarcate the musical topography of the Spiš/Zips region focusing on individual local settlements (towns, villages, monasteries, aristocratic residences). Creating a topographic network of Spiš in the Early Modern Period requires music-historical research at least from five angles of view: research on musical sources, on historical musical instruments, on chronicles and contemporaneous prints, on archival sources and research on historical maps. However, towns (civitas, oppidum) certainly form the basic topographic unit of research. The primary musical hubs in Spiš included the cities that joined Luther's Reformation movement and had an ethnically mixed, prevailingly Slovak-German population. The specification of the music-topographic network of Spiš enables us to identify the locally and denominationally differentiated musical life of the towns of this region.

Key words: Regional musicology, musical topography, musical culture, history of music in the Spiš/Zips region

\section{Úvod}

Pojem topografia (z gr. topos = miest, graphos - opis, zobrazenie) je prienikový pojem medzi geodéziou a kartografiou, ktorým sa v úzkom zmysle slova označuje vedecká disciplína zaoberajúca sa tvarom, opisom, meraním a zobrazením zemského povrchu. Hlavným predmetom jej záujmu je reliéf zemského povrchu, vodné toky a plochy, rastlinstvo a objekty vytvorené človekom. V staršej vedeckej literatúre sa tento pojem používal na geografický opis ludských sídlisk a jeho ekvivalentom bol termín miestopis. ${ }^{1}$ $\mathrm{V}$ takomto ponímaní sa preniesol aj do hudobnej historiografie, ktorá pod pojmom hudobný miestopis rozumela výskum hudobnej kultúry v ludských sídlach, v ktorých sa pestovala hudba. Týkalo sa to základných demografických administratívno-správnych sídel (mestá, obce) a špeciálnych sídel, napríklad cirkevných (kostoly, kláštory) 
a súkromných (šlachtické rezidencie, hrady, zámky). ${ }^{2}$ Prvé pokusy o hodnotenie dejín hudobného života v mestách na Slovensku sa objavili v období vojnového Slovenského štátu, pričom podla množstva zachovaných hudobných prameňov bud’ išlo o kratšie štúdie, napríklad k dejinám cirkevnej hudby baníckych miest na južnom Spiši - Gelnica, Smolník, Švedlár v 18. a 19. storočí (Zagiba 1939)³ -, alebo išlo o knižné monografie, z nich najznámejšia je publikácia Hudba v Banskej Bystrici, venovaná hudobnému životu a repertoáru jedného mesta od stredoveku do 19. storočia, do ktorej sú zaradené aj hudobné ukážky rukopisov a transkripcie skladieb (Hudec 1944). ${ }^{4}$

Po druhej svetovej vojne sa stala primárnou v slovenskej historickej muzikológii heuristika, teda systematické vyhladávanie a dokumentácia hudobných prameňov, ktorá podnietila budovanie zbierkového fondu v Slovenskom národnom múzeu-Hudobnom múzeu a vznik Slovenského katalógu hudobnohistorických prameňov. ${ }^{5}$ Intenzívny výskum prebiehal aj v českej muzikológii, kde $\mathrm{v} 60$. rokoch minulého storočia detailné hudobnotopografické aktivity muzikológov na Morave priniesli celý rad objavov hudobných prameňov i dovtedy neznámych hudobných lokalít. ${ }^{6}$ Geograficky presne lokalizované výskumy si vyžiadali následnú komparáciu a hodnotenie javov z hladiska vztahov $\mathrm{k}$ príslušnej lokalite, $\mathrm{k}$ regiónu, $\mathrm{k}$ aktuálnym štátnym hraniciam, resp. $\mathrm{k}$ bývalým historickým hraniciam štátnych útvarov. Cielom výskumov bolo charakterizovat jednotlivé hudobné javy, identifikovat významné hudobné centrá a porovnávat ich medzi sebou. V tom období už išlo o celoeurópsky trend vo výskume dejín hudby $\mathrm{v}$ mestách a regiónoch nielen $\mathrm{v}$ muzikológii, ale aj $\mathrm{v}$ etnológii. $\mathrm{V}$ hudobnej historiografii sa kreovala porovnávacia hudobná topografia, ktorá hodnotila a porovnávala hudobný život jednotlivých lokalít $\mathrm{v}$ regionálnom aj nadregionálnom kontexte. ${ }^{7}$

Výskum hudobných prameňov na Slovensku bol zo začiatku primárne vlastivedne orientovaný, postupne sa však dostal na vysokú úroveň teoretického interdisciplinárneho uvažovania; išlo o hodnotenie regionálnych aspektov kultúrnych javov z hladiska historickej muzikológie, etnomuzikológie, organológie a hudobnej sociológie. Richard Rybarič aplikoval túto líniu výskumu na obdobie stredoveku, pričom za ciel systematickej porovnávacej hudobnej topografie určil výskum hudobného života stredovekých

2 RYBARIČ, Richard: Dejiny hudobnej kultúry na Slovensku, I. : Stredovek, renesancia, barok. Bratislava : OPUS, 1984, s. 38-40.

3 ZAGIBA, František: Z dejín barokovej cirkevnej hudby na južnom Spiši. In: Kultúra, roč. 11, 1939. Red. Ján Pöstényi. Trnava : Spolok Sv. Vojtecha, s. 182-184.

4 HUDEC, Konštantín: Hudba v Banskej Bystrici do 19. storočia. Liptovský sv. Mikuláš : Tranoscius, 1941.

5 Centrálnu evidenciu hudobných prameňov zastrešuje od roku 1967 SNM-Hudobné múzeum v Bratislave (bývalé Hudobné oddelenie Historického ústavu SNM). BUGALOVÁ, Edita: Hudobné pramene - kultúrne dedičstvo Slovenska. Poznámky k vývoju tezaurácie hudobných prameňov na Slovensku. In: Hudobné pramene - kultúrne dedičstvo Slovenska. Ed. Edita Bugalová. Bratislava : Slovenská muzikologická asociácia, SNM-Hudobné múzeum, 2011, s. 5-10. KALINAYOVÁ-BARTOVÁ, Jana a kol.: Sprievodca po zbierkovom fonde Hudobného múzea Slovenského národného múzea I. Hudobné zbierky archívnej povahy, 1965 - 2000 (= Musaeum Musicum). Bratislava : SNM-Hudobné múzeum, 2001. DAS LEHOTSKÁ, Miriam: Pramene hudby na Slovensku v medzinárodnom kontexte. In: Múzeum, roč. 64, 2018, č. 2, s. 4-6.

6 Kapitoly z hudební topografie. In: Opus musicum, roč. 1, 1969.

7 FELDMANN, Fritz: Einige Grundgedanken zur Musik-Topographie. In: Musik des Ostens 5. Sammelbände der J. G. Herder-Forschungsstelle für Musikgeschichte, 1969, s. 163. 
miest na Slovensku, zameraný na vyhladávanie a dokumentáciu hudobných pamiatok, výskum sekundárnych hudobných prameňov a ikonografie, kombinovaný s pomocnými vedami (kodikológia, dejiny cirkevnej hudby). Od 70. rokov minulého storočia sa tento trend v slovenskej hudobnej historiografii prejavil zvýšeným záujmom o hudobnú topografiu od najstarších dejín hudby až do obdobia klasicizmu. ${ }^{8}$ Systematickú pozornost' hudobnému miestopisu venoval Richard Rybarič neskôr nielen pri výskumoch obdobia stredoveku, ale aj raného novoveku; pričom definoval štruktúru hudobného života v mestách na Slovensku a analyzoval podmienky a inštitucionálnu základňu pestovania hudby. V monografii Dejiny hudobnej kultúry na Slovensku I. (1984) v stati Renesančné mesto ako hudobnokultúrny organizmus uviedol: „O hudobnej kultúre Slovenska, o osudoch náročnej hudby v tomto období totiž nerozhodovali, na rozdiel od iných krajín, královské dvory a kniežatá, exkluzívne katedrály s evidentnou snahou reprezentovat' a manifestovat' bohatstvo, vplyv a slávu mocných tohto sveta, ale hlavné piliere hudobného života na Slovensku v 15. - 17. storočí predstavujú mestá, kde reálne zmýšlajúcim obchodníkom a remeselníkom nešlo v prvom rade o honosné a nákladné hudobné predstavenia, lež o dôstojný a solídny rámec každodenného života". 9

Hudobná kultúra európskych miest $\mathrm{v}$ ranom novoveku je napokon dlhodobo v centre pozornosti hudobných historikov. Pri tejto problematike je však viac než inde potrebná spolupráca so všeobecnými historikmi, ktorí sledujú vývin miest z celkového hladiska dejinných procesov, čím pomáhajú odhalovat medzimestské regionálne i nadregionálne vztahy. Jedným z takýchto zaujímavých historických regiónov Európy je Sliezsko ležiace na prihraničnom území. Evidujeme dlhodobý záujem o jeho dynamicky premenlivé dejiny; nemeckí historici zmapovali sliezske mestá v encyklopedickom projekte výskumu urbánnych dejín jednotlivých regiónov, pričom $\mathrm{k}$ dejinám sliezskych miest existuje až 531 hesiel analyzujúcich mestá, obce, kláštory, kaštiele a d’alšie historicky dôležité lokality (Weczerka 2003). V stredoeurópskej muzikológii je Sliezsko tiež v hladáčiku hudobných historikov v úzkej cezhraničnej kooperácii. Jednou z úspešných platforiem tejto spolupráce je pol'ský projekt Tradycje śląskiej kultury muzycznej v gescii Hudobnej akadémie Karola Lipińského vo Vroclave. Od roku 1980 sa tu prezentujú nové poznatky k dejinám bohatého hudobného života regiónu Sliezska ako kultúrne dôležitej časti Európy. ${ }^{10} \mathrm{~K}$ zaujímavým viacročným projektom

8 RYBARIČ, Richard: Stredoveké mesto ako hudobnokultúrny organizmus. In: Historické štúdie 19, Bratislava : Veda, vydavatelstvo SAV, 1974, s. 190. Spišské mestá v stredoveku. Ed. Richard Marsina. Košice : Východoslovenské vydavatelstvo, 1974. Význam stredovekých miest na území dnešného Slovenska potvrdzujú aj aktuálne výskumy historikov, ktorí prisúdili status mesta v stredoveku štyridsiatim siedmim lokalitám na Slovensku. Lexikón stredovekých miest na Slovensku. Eds. Martin Štefánik, Ján Lukačka et al. Bratislava : Historický ústav SAV; Prodama, 2010.

9 RYBARIČ, Ref. 2, Kapitola „Renesančná a baroková hudba“, podkapitola „Hudobný život na Slovensku v 15. - 17. storočí", s. 39-45. Richard Rybarič sa dlhodobo venoval výskumu hudobnej kultúry miest na Slovensku v spolupráci so všeobecnými historikmi a zásadnú štúdiu v tomto smere publikoval už v roku 1974. RYBARIČ, Ref. 8, s. 181-192.

10 Projekty Handbuch der historischen Stätten Deutschlands (Stuttgart od roku 1958), Handbuch der historischen Stätten (Stuttgart od roku 1966). Pozri: Handbuch der historischen Stätten, Bd. 1. Schlesien. Ed. Hugo Weczerka. Stuttgart, 1977, ${ }^{2} 2003$. Projekt Tradycje śląskiej kultury muzycznej, od roku 1980 v gescii Katedry teórie hudby a histórie hudobnej kultúry Sliezska Hudobnej aka- 
relevantným k oblasti hudobnej regionalistiky a topografie patrí moravský projekt Výzkumné sondy k dějinám hudebni kultury na Moravě, préedevším v Brně (siedmy ročník v roku 2020), riešený v Ústave hudební vědy Filozofickej fakulty Masarykovej univerzity v Brne, ktorého cielom je výskum dejín hudobného a umeleckého života lokalít so zameraním na hudobné osobnosti a hudobné inštitúcie v regióne. ${ }^{11}$

Metodologické uchopenie výskumu hudobného života miest poskytuje viacero možností podla predmetu, resp. rozsahu bádania; pät základných najčastejšie používaných predstavil Jan Bata (2009): 1) komplexný opis hudobného diania v jednom meste v čo najväčšej úplnosti, 2) opis so zameraním sa na vybrané dôležité inštitúcie ovplyvňujúce hudobné dianie, 3) opis hudobnej kultúry v meste z hladiska jedného hudobného žánra, resp. druhu (napr. pestovanie polyfonickej hudby), 4) opis mestskej hudobnej kultúry $\mathrm{z}$ hladiska vybraného sociologického problému (mecenášstvo, konfesionalita), 5) opis typu mozaikovitého, komplexného uchopenia problematiky v kolektívnej monografii, resp. konferenčnom zborníku. ${ }^{12} \mathrm{~V}$ európskej muzikológii sa $\mathrm{v}$ súčasnosti dostávajú do popredia viac otázky výskumu hudobnej kultúry miest $\mathrm{z}$ iných aspektov (antropologických, kulturologických), ako napríklad identita a etnicita, subjektivita, genderové štúdiá, kultúrne stereotypy. Napriek týmto moderným trendom sa ukazuje, že v historickej muzikológii je návrat ku klasickým metódam hudobnej regionalistiky s použitím komparatívnych databáz stále produktívny; svedčia o tom napríklad výsledky výskumov medzinárodných tímov zaoberajúcich sa problematikou migrácie v hudbe. ${ }^{13}$ Skúmat migráciu si totiž priamo vyžaduje vytvárat variabilné hudobnotopografické siete či už z mestských sídel, inštitúcií alebo lokalít na rôznych územiach v Európe. Sledovat migráciu znamená sledovat cesty hudby, spoznávat' mobilitu hudobníkov, presuny hudobných prameňov, identifikovat kultúrne vzory a miesta stretu hudobných vplyvov, čo umožňuje hlbšie pochopit dynamiku európskej hudobnokultúrnej scény a kohézne sily prispievajúce k vytváraniu spoločnej európskej kultúrnej identity.

V slovenskej hudobnej historiografii sa hudobnotopografický výskum zvyčajne spájal predovšetkým s oblastou výskumu dejín hudby v období klasicizmu, z ktorého sa zachovalo väčšie množstvo prameňov potrebných na ich komparáciu v jednotlivých lokalitách na regionálnej i celoštátnej úrovni. Od spomínaných 70. rokov nájdeme

démie Karola Lipińského vo Vroclave. Aktuálne vyšiel tlačou 15. zväzok zborníka z konferencií usporiadaných v rámci tohto projektu. Pozri: Tradycje ślaskiej kultury muzycznej. Tom XV. Eds. Anna Granat-Janki et al. Wrocław : Akademia Muzyczna im. Karola Lipińskiego we Wrocławiu, 2020. Dostupné na internete: https://www.dbc.wroc.pl/publication/150729.

11 Výzkumné sondy $k$ dějinám hudební kultury na Moravě, především v Brně (zodpovedný riešitel Petr Macek, 2020). Dostupné na internete: https://www.muni.cz/vyzkum/projekty/54568.

12 BAŤA, Jan: Hudební kultura renesančního města jako téma. In: Acta musicologica, 2009, č. 2. Dostupné na internete: http://acta.musicologica.cz/09-02/0902s01.html.

13 Music Migration in the Early Modern Age: Centres and Peripheries - People, Works, Styles, Paths of Dissemination and Influence. Eds. Jolanta Guzy-Pasiak, Aneta Markuszewska. Warsaw : Liber Pro Arte, 2016. Music Migrations in the Early Modern Age: People, Markets, Patterns and Styles. / Glazbene migracije u rano moderno doba: ljudi, tržišta, obrasci i stilovi (= Muzikološki Zbornici 18). Ed. Vjera Katalinić. Zagreb : Croatian Musicological Society, 2016. Musicians' Mobilities and Music Migrations in Early Modern Europe: Biographical Patterns and Cultural Exchanges. Eds. Gesa zur Nieden, Berthold Over (= Mainz Historical and Cultural Sciences 33). Bielefeld : Transcript-Verlag, 2016. 
tento typ bádania v tažiskových prácach Dariny Múdrej, ktorá v súvislosti s analýzou hudobného života v období klasicizmu zaradila do publikácie Pramene slovenskej hudby aj kapitolu Topografia hudby klasicizmu (1977). V tejto kapitole cielene charakterizovala základné poznatky o hudobnom živote miest podla geograficky ohraničených oblastí vyčlenených podla množstva zachovaných hudobných prameňov: 1) Bratislava a juhozápadné Slovensko (Trnava, Jur pri Bratislave, Mariánka, Vel'ké Leváre, Dolná Krupá, Skalica, Modra, Šaštín); 2) Trenčín a okolité mestá (Ilava, Nové Mesto nad Váhom, Pruské, Púchov); 3) stredoslovenské banské mestá (Banská Štiavnica, Kremnica); 4) Spiš (Spišská Kapitula, Podolínec, Kežmarok, Lubica, Levoča, Spišské Podhradie, Spišská Nová Ves, Švedlár, Smolník, etc.); 5) Košice a ostatné východoslovenské lokality (Rožňava, Jasov, Fintice, Gelnica, Prešov, etc.). ${ }^{14}$ Neskôr sa tiež sústredila na topografické členenie problematiky dejín hudby a v syntetickej monografii Dejiny hudobnej kultúry na Slovensku II (1993) zohladnila administratívno-správne teritoriálne hladiská vo vývinovom historickom kontexte (mestá, stolice, župy, regióny, geografické okruhy). ${ }^{15}$ Tento trend dlhoročného výskumu zúročila v najnovšej práci Topografia hudby klasicizmu z pohladu kanonických vizitácií (2019). ${ }^{16}$

V moravskej, resp. brnianskej muzikológii sa v súvislosti s hudobnotopografickým výskumom postupne kreovala špecifická muzikologická disciplína - hudobná regionalistika, zameraná na „výskum hudobného diania v presne vymedzených topograficko-regionálnych súvislostiach“; v tomto kontexte je stanovené aj metodologické východisko: „Východiskem je tu hudebně topografické bádání, t. j. komplexné studium hudebního dění jednotlivých lokalit, výsledkem je pak mj. typologie hudebních lokalit, $\mathrm{k}$ níž se dospívá komparací struktur a kapacit hudebního života jednotlivých míst v celém historicky sledovatelném rozsahu (lokality sa třídí podle úlohy, jakou hrály v jednotlivých epochách; rozlišují se místa převažne přijímajíci podnety, místa s částečnou produkční soběstačností a centra vyzařující podněty do jiných lokalit; ... (Fukač - Vysloužil 1997). ${ }^{17} \mathrm{~V}$ súčasnosti česká muzikológia zaznamenáva zvýšené aktivity pri objasňovaní dejín jednotlivých miest, resp. lokálnych a regionálnych dejín (Aschenbrenner 2011, 2013; Sehnal 2001, 2002); ${ }^{18}$ spomeňme bližšie aspoň bádania zamerané na moravskú hudobnú topografiu raného novoveku, ktoré priniesli nové poznatky $\mathrm{k}$ dejinám hudobného života náboženských bratstiev na Morave a k analýze a edícii hudobných inventárov - unikátnych prameňov $\mathrm{k}$ dejinám hudobného repertoáru v kostoloch, mestách, biskupských rezidenciách (Maňas 2008, 2016). V prípade

14 MÚDRA, Darina: Topografia hudby klasicizmu. Tvorba obdobia klasicizmu. In: Pramene slovenskej hudby. Bratislava : SNM, 1977, s. 63-74.

15 MÚDRA, Darina: Dejiny hudobnej kultúry na Slovensku II. Klasicizmus. Bratislava : OPUS, 1993.

16 MÚDRA, Darina: Topografia hudby klasicizmu z pohladu kanonických vizitácí, 3 zv. Bratislava : Veda, vydavatel'stvo SAV, 2019.

17 Hudební regionalistika [heslo]. In: Slovník české hudební kultury. Eds. Jiří Fukač, Jiří Vysloužil, Petr Macek. Praha : Editio Supraphon, 1997, s. 329-330.

18 ASCHENBRENNER, Vít: Hudebnè-liturgický provoz jezuitské koleje v Klatovech v 18. století. Praha : Západočeská univerzita v Plzni; Scriptorium, 2011. ASCHENBRENNER, Vít: Hudební kultura v Klatovech 17. a 18. století z hlediska hudební regionalistiky - možnosti a limity výzkumu. In: Muzikologické fórum, roč. 2, 2013, č. 2, s. 133-146. SEHNAL, Jiří - VYSLOUŽIL, Jiří: Dějiny hudby na Moravě. (= Vlastivěda moravská. Země a lid, nová řada. Svazek 12). Brno : Muzejní a vlastivědná společnost v Brně, 2001. 
výskumu náboženských bratstiev ide o analýzu jedného špecifického hudobného javu $\mathrm{v}$ početných lokalitách, $\mathrm{v}$ ktorých sa porovnávajú spoločné znaky $\mathrm{v}$ celoeurópskom kontexte. Autor výskumu Vladimír Maňas dospel híbkovou analýzou hudobných a archívnych prameňov $\mathrm{k}$ modernému, nenacionalizovanému hodnoteniu hudobných javov v komunite fungovania náboženských bratstiev ako súčasti európskych kultúrno-historických a nábožensko-sociologických dejín. ${ }^{19}$

V stredoeurópskej muzikológii sa aktuálne otázky hudobnej regionalistiky riešia viac-menej permanentne, a $\mathrm{v}$ to nielen $\mathrm{v}$ rovine praktických heuristických výskumov od 60. rokov minulého storočia (výskum osobností, tvorby, migrácia hudby), ale aj $\mathrm{v}$ teoretickej rovine; najprepracovanejšiu klasifikáciu problematiky nájdeme u Richarda Rybariča, ktorý označil hudobnohistorickú regionalistiku za bázu, bez ktorej sa nedajú budovat' vel'ké syntetické koncepty a koncepcie, tiež charakterizoval regionalistický výskum ako „hĺbkové, systematické a monografické skúmanie hudobnej minulosti Slovenska koncentrované na jednotlivé mestá, oblasti, inštitúcie a osobnosti“ ${ }^{20}$ Dôkladné rozpracovanie takýchto teoretických otázok v bývalej Československej socialistickej republike napokon zodpovedalo potrebám vtedajšej hudobnej historiografie. Až po roku 1990 došlo k naplneniu internacionálneho bádania bez obmedzení a vtedy sa jasne ukázalo, že pre územie strednej Európy sú metodologické otázky vymedzenia geografických hraníc výskumu hudobných javov omnoho dôležitejšie než pre ostatné územia Európy. ${ }^{21}$ Vývoj hudby v strednej Európe prebiehal v paralelných vývojových líniách, v ktorých existovala špecifická hudobná kultúra $\mathrm{v}$ rôznych lokalitách, či už v hranične ucelených regiónoch (Spiš, Šariš, Sliezsko, Morava), alebo na územiach geograficky premenlivých, na ktorých hudobné vztahy záviseli od administratívnych, inštitucionálnych a iných kontextuálnych, dynamicky sa meniacich spoločenských javov.

$\mathrm{V}$ súčasnosti sú $\mathrm{v}$ muzikológii definované pojmy hudobnohistorická regionalistika a hudobnohistorická topografia ako dve významovo samostatné kategórie. Zastrešuje ich kategória hudobnej regionalistiky, ktorej cielom je komplexný hudobnohistorický, etnomuzikologický, hudobnosociologický, hudobnoantropologický, etc. výskum hudby a hudobnej kultúry v presne vymedzených geografických, ekonomických, administratívno-správnych územiach rôznej vel'kosti, ktoré sú nositelmi hudobnokultúrnych súvztažností. ${ }^{22}$ Takýto výskum totiž umožňuje nielen modelovat rôzne typy hudobno-

19 MAŇAS, Vladimír: Hudební aktivity náboženských korporací na Moravě v raném novověku. Brno : [s.n.], 2008. Dostupné na internete: http://is.muni.cz/th/13678/ff_d/. MAŇAS, Vladimír: K problematice hudebních inventářů: několik doplňujících poznámek k heslu Katalog Jiř́ho Fukače ve Slovníku české hudební kultury. In: Musicologica Brunensia, roč. 51, 2016, č. 2, s. 81-94. Dostupné na internete: https://digilib.phil.muni.cz/bitstream/handle/11222.digilib/136139/1_ MusicologicaBrunensia_51-2016-2_9.pdf?sequence=1.

20 RYBARIČ, Richard: O niektorých problémoch hudobnohistorickej regionalistiky. Strojopis. Bratislava, 1982.

${ }^{21}$ Musik Mitteleuropas in der 2. Hälfte des 18. Jahrhunderts (= Historia musicae Europae centralis 1). Ed. Pavol Polák. Bratislava : Ústav hudobnej vedy SAV; ASCO Art \& Science, 1993. Mitteleuropäische Kontexte der Barockmusik (= Historia musicae Europae centralis 2). Ed. Pavol Polák. Bratislava : Slowakische Musikunion, Academic Electronic Press, 1997.

22 PETÖCZOVÁ, Janka: Hudobnoregionalistický výskum na Slovensku z aspektu historickej muzikológie. Regional Musicological Research in Slovakia from the Aspect of Historical Musicology. In: Vedecký časopis o kultúre regiónov na Slovensku, roč. 2, 2018, č. 2, s. 1-62. Dostupné na internete: http://csr.sk/wp-content/uploads/2019/01/CSR-Volume-2-2018-2.pdf. 
topografických sietí v geograficky a administratívne premenlivých hudobnokultúrnych areáloch, ale zároveň poskytuje možnost’ lepšie identifikovat’ a charakterizovat' systém vztahov a mechanizmov, ktoré robia dejiny hudby a hudobnej kultúry vymedzeného regiónu špecifickými, resp. jedinečnými. Základným výsledkom topografického výskumu v dejinách hudby je vytvorenie hudobnotopografickej siete, ktorej jednotlivé prvky sú spojené hudobnými súvislostami (migrácia hudobníkov, presuny hudobných prameňov, šírenie hudobného repertoáru, univerzitné štúdium v zahraničí a získavanie hudobných skúseností, vzt’ahy medzi hudobnými inštitúciami, kontexty prenosu poznatkov pri pracovných aktivitách hudobných nástrojárov, hlavne pri výstavbe historických organov, etc.).

\section{Hudobnotopografické výskumy Spiša}

Dejiny hudby na Spiši trvale pútajú pozornost’ hudobných historikov. Hlavným cielom ich poznania sú pramene polyfonickej hudby v mestách ovplyvnených nemeckou reformáciou. Prvý profesionálny hudobný historik, profesor Dobroslav Orel už v roku 1923 navštívil Spiš, kde uskutočnil výskum hudobných prameňov v Levoči, Poprade a Kežmarku. Služobnú cestu z Bratislavy po Slovensku absolvoval spolu s Antonínom Hořejšom a detaily $z$ tejto cesty poznáme vd’aka zachovanej správe, ktorej účelom bolo „... zjistiti v archivech farních, v musejích městských a zámeckých i na kostelních kruchtách rukopisy, staré tisky a literární díla týkajíci se hudby, je skatalogisovati pro centrální hudební archiv při hudebně vědeckém semináři filosofické fakulty university Komenského, př́padně něco z těchto památek získati pro seminární knihovnu“. Okrem správy z tejto služobnej cesty sa zachoval aj dokument z 2. novembra 1923 o výpožičke hudobnohistorických prameňov z Levoče, v ktorom nájdeme zdôvodnenie výpožičky: „... Die hohe Kultur der ev. Gemeinde unter der Tatra verdient es, dass auch ihre Musik wissenschaftlich bearbeitet werde."23

Dobroslav Orel a Antonín Hořejš navštívili okrem troch spomínaných spišských miest ešte Košice, Žilinu, Liptovský Mikuláš, Ružomberok a Dolný Kubín. Pozornost' obidvoch historikov však zaujala predovšetkým Levoča, mesto so zachovanou unikátnou evanjelickou zbierkou hudobnín, ktorej súčastou sú aj vzácne rukopisné zborníky písané nemeckou organovou tabulatúrnou notáciou. ${ }^{24}$ Tieto pramene sa stali na dlhý čas základným zdrojom poznatkov o hudobnej kultúre Spiša v 17. storočí; z nich predovšetkým dva tabulatúrne zborníky, ktoré obsahujú hudbu spišských skladatelov Samuela Marckfelnera (zborník sign. SK-Le MUS A 5), organistu v Levoči, a Jána Šimráka st. (Johann Schimrack sen.), organistu v Spišskom Podhradí (zborník

23 „Zpráva o studijní cestě prof. Dobroslava Orla o prázdninách 1923“. Registratúrne stredisko FiF UK, Bratislava, Personálne oddelenie, Osobný spis Dobroslav Orel, agenda Hudobného seminára FiF UK v Bratislave 1922 - 1925, čj. 150, hs 1925.

24 D. O. [Dobroslav Orel]: Slovensko. In: Pazdírkưv hudební slovník naučný I. Část věcná. Ed. Gracian Černušák. Brno : Nákladem Ol. Pazdírka, 1929, s. 370. Konštantín Hudec: Vývin hudobnej kultúry na Slovensku. Bratislava : Slovenská akadémia vied a umení, 1949, s. 35, 36. BURLAS, Ladislav - FIŠER, Ján - HOŘEJŠ, Antonín (eds.): Hudba na Slovensku v 17. storočí. Bratislava : Vydavatel'stvo SAV, 1954, kapitola „HOŘEJŠ, Antonín: Levočské tabulatúrne zborníky“, s. 96154. 
sign. SK-Le MUS A 3). ${ }^{25} \mathrm{~V}$ týchto zborníkoch sú za viacerými skladbami uvedené aj dátumy odpisov a miesta, kde sa odpisy realizovali; zo spišských miest to bola Levoča, Spišské Podhradie, Lubica a Smolník. Všetky tieto lokality sa následne dostali do pozornosti bádatelov, rovnako $\mathrm{v}$ rovine výskumu primárnych, ako aj sekundárnych prameňov. Primárne hudobné pramene z obdobia raného novoveku sa však nezachovali vo všetkých týchto lokalitách, napríklad v Spišskom Podhradí sa nezachoval ani vtedajší farský kostol (pôvodný stredoveký kostol, v 17. storočí evanjelický), v ktorom Ján Šimrák st. pôsobil. Na zoznam spišských miest zaujímavých pre hudobnú historiografiu Richard Rybarič napokon zaradil ako prominentné mestá Levoču, Lubicu, Spišské Podhradie, Kežmarok a Spišskú Novú Ves. ${ }^{26}$ Tieto mestá patria aj v súčasnosti k najviac sledovaným mestám zo Spiša v celoslovenskom kontexte výskumu starších dejín hudby. ${ }^{27}$

Mimoriadne postavenie regiónu Spiša ako samostatnej výskumnej hudobnotopografickej jednotky sa ukázalo aj pri teritoriálnom členení celoslovenských výskumov. Štandardne v nich dominujú tri, resp. štyri výskumné hudobnokultúrne okruhy, ktoré poskytujú základ na vytváranie hudobnotopografických sietí na území súčasného Slovenska: 1) v starších dejinách je to „západoslovenský okruh, spišsko-východoslovenský okruh a oblast' stredoslovenských banských miest" (Rybarič 1984), ${ }^{28}$ resp. "Bratislava a západné Slovensko, bohaté stredoslovenské banské mestá, Spišs centrom Levočou (neskôr Podolíncom) a východné Slovensko s Bardejovom, Prešovom a Košicami“ (Kačic 1996);29 2) v klasicizme je to „západoslovenský, stredoslovenský, spišský a východoslovenský okruh" (Múdra 1993). ${ }^{30} \mathrm{~V}$ období klasicizmu bol Spiš ako samostatný hudobnokultúrny okruh vyčlenený na základe detailného výskumu prameňov, ktorých sa zachovalo z 18. storočia neporovnatelne väčšie množstvo než z predchádzajúcich storočí. Ukázali to v podstate už prvé výsledky heuristických výskumov, ktoré Darina Múdra realizovala v 70. rokoch; vtedy rozčlenila výskumnú sféru na pät geograficko-kultúrnych oblastí Slovenska: Bratislava a juhozápadné Slovensko (Trnava, Jur pri Bratislave, Mariánka, Velké Leváre, Dolná Krupá, Skalica, Modra, Šaštín); Trenčín a okolité mestá (Ilava, Nové Mesto nad Váhom, Pruské, Púchov); stredoslovenské banské mestá (Banská Štiavnica, Kremnica); Spiš (Spišská Kapitula, Podolínec, Kežmarok, Lubica, Levoča, Spišské Podhradie, Spišská Nová Ves, Švedlár, Smolník, etc.); Košice a ostatné východoslovenské lokality (Rožňava, Jasov, Fintice, Gelnica, Prešov, etc.). Uviedla pritom aj dôvody jedinečnosti a svojrázu hudobnej kultúry Spiša, kto-

25 MATÚŠ, František (trans. a ed.): Tabulatúrny zborník Samuela Marckfelnera (Výber) (= Stará hudba na Slovensku 4). Bratislava : OPUS, 1981. RYBARIČ, Richard: Ján Šimbracký [sic, NB Šimrák st.] - spišský polyfonik 17. storočia. In: Musicologica Slovaca, roč. 4, 1973, s. 43. RYBARIČ, Ref. 2, s. 43.

27 PETÖCZOVÁ, Janka: Polychorická hudba II, na Spiši v 17. storočí. Prešov : František Matúš, 1999. HULKOVÁ, Marta: Hudobná kultúra v mestách a regiónoch v 16. storočí na území Slovenska. In: Hudobnohistorický výskum na Slovensku začiatkom 21. storočia II. Ed. Marta Hulková. Bratislava : Stimul, 2010, s. 173-199.

28 RYBARIČ, Ref. 2, kapitola „Renesančné a barokové hudobnokultúrne strediská a okruhy“, s. 46.

29 KAČIC, Ladislav: Od stredoveku po renesanciu. Barok. In: Dejiny slovenskej hudby od najstarších čias po súčasnost. Ed. Oskár Elschek. Bratislava : Ústav hudobnej vedy SAV, ASCO Art et Science 1996, kapitola „Centrá - okruhy - repertoár“, s. 81-84.

30 MÚDRA, Ref. 15, kapitola „Hudobnokultúrne okruhy a strediská“, s. 28-39. 
ré vyplynuli z celkového „charakteru kultúrneho prejavu v 18. storočí, z komplikovaných konfesionálnych vztahov a zo spolužitia Slovákov, Nemcov a Madarov“ (1977). ${ }^{31}$ $\mathrm{V}$ podstate vo všetkých týchto teritoriálnych deleniach vystupuje Spiš do popredia ako jedinečná výskumná lokalita, čo je v porovnaní so staršími hudobnohistorickými prácami pozitívna skutočnost’; ved' v prvých akademických dejinách hudby (1957) sa spomínali pri prezentovaní urbánneho hudobného života v období klasicizmu len mestá Bratislava, Trnava, Košice, Kremnica, Trenčín, Banská Bystrica, Banská Štiavnica, Krupina, ale ani jedno spišské mesto. ${ }^{32}$

\section{Hudobná topografia Spiša}

Regionálny výskum dejín hudby a hudobnej kultúry na Spiši z hladiska hudobnej topografie si vyžaduje metodologické rozčlenenie na dve základné línie: 1) vytýčenie hudobnotopografickej siete vnútri jednotlivých lokálnych sídel (mesto, obec, kláštor, šlachtické sídlo), čiže výskum ich vnútorných hudobných vzt’ahov; 2) vytýčenie hudobnotopografickej siete $v$ geografických hraniciach historického regiónu Spiš (Spišská stolica), a teda výskum vonkajších hudobných vztahov medzi jednotlivými sídlami. Na tomto základe je potom možné pokračovat’ v odhal'ovaní hudobných súvislostí v geograficky blízkych, hraničných regiónoch (Šariš, Gemer, Liptov, Malopol’sko) a tiež v teritoriálne širšom stredoeurópskom priestore. Napriek mnohým štúdiám k hudobným dejinám Spiša nie je ani v jednej z týchto dvoch línií ukončený komplexný výskum. Isté je, že základnou skúmanou hudobnotopografickou jednotkou v ranom novoveku je mesto (civitas, oppidum), a že pre spišské mestá platili všeobecne uznávané premisy: 1) v každom meste pôsobili dve inštitúcie usmerňujúce vývoj umeleckej hudby: kostol a škola; 2) mestá zamestnávali profesionálnych hudobníkov - kantor, organista, trubač (resp. inštrumentalista); 3) k prvoradým významným hudobným centrám patrili mestá s národnostne zmiešaným (prevažne slovensko-nemeckým) obyvatel’stvom a tie, ktoré sa pripojili k Lutherovmu reformačnému hnutiu; z nich najdôležitejšia úloha pripadla bohatým a kultúrne aktívnym slobodným královským mestám. ${ }^{33}$

Pre Spiš to platí nielen pri výskume hudby obdobia renesancie, ale aj celého raného novoveku, resp. až do obdobia neskorého klasicizmu. V dejinách hudby na území historických regiónov súčasného východného Slovenska totiž nedominovali královské dvory, paláce kniežat a exkluzívne katedrály. Hudobná kultúra sa tu rozvíjala predovšetkým v intenciách mestských sídel. Prvý krok k výskumu hudby na Spiši môžeme zacielit na sedem miest - Gelnica, Kežmarok, Levoča, Spišská Nová Ves, Spišská Sobota, Spišské Vlachy a Stará Lubovňa; tieto boli označené všeobecnými historikmi ako životaschopné, rozvíjajúce sa mestské sídla už v stredoveku. ${ }^{34}$ Pravdaže, na roz-

31 MÚDRA, Ref. 14, s. 68.

32 Dejiny slovenskej hudby. Bratislava : Vydavatel'stvo SAV, 1957, kapitola: HRUŠOVSKÝ, Ivan: „Klasicistická hudba na prelome 18. a 19. storočia“, s. 157-216.

33 RYBARIČ, Ref. 2, s. 39-45.

34 Lexikón stredovekých miest na Slovensku, Ref. 8. Východisko k charakteristike každého mesta tvorí o. i. aj jeho poloha, prírodné podmienky, mestské privilégiá, mestské právo, stavebný vývoj a topografia mesta (formovanie mestského jadra a predmestí, charakter zástavby, opevnenie, ar- 
voj kultúry poskytovali najviac financií tie najbohatšie - dve slobodné královské mestá Levoča (Leutschau) a Kežmarok (Kesmark). Ony reprezentovali tento región ako symboly rozvoja architektúry, výtvarného i hudobného umenia na Spiši, a napokon - v súčasnosti ich považujeme za najlepšie preskúmané mestá, predovšetkým vd’aka zachovaným hudobným prameňom. Levoča je dlhodobo v centre pozornosti vdaka zbierke hudobnín v evanjelickom kostole a tiež vd’aka osobnosti Samuela Marckfelnera (1621 - 1674), jedného z najznámejších levočských organistov. ${ }^{35}$ Kežmarok sa dostal do centra pozornosti neskôr v súvislosti s objavom hudby Thomasa Goslera v tabulatúrnom zborníku sign. SK-Le MUS A 3 (olim 13992). Thomas Gosler (Goslerus de Zeger; ? - po 1646) nepôsobil vo funkcii mestského hudobníka, pracoval v Kežmarku v rokoch 1625 - 1646 ako notár a bol aj školským inšpektorom. Jeho osudy sú zaujímavé z hladiska migrácie - pochádzal z mesta Flensburg (dnes SRN, na hranici s Dánskom) a na Spiš prišiel ako exulant cez Sliezsko a Moravu. ${ }^{36}$ Popri Levoči a Kežmarku sa pozornosti zo strany hudobných historikov dostáva aktuálne aj mestu Spišská Nová Ves (Neudorf, Igló), kde pôsobil v rokoch 1625 - 1628 ako rektor mestskej latinskej školy Juraj (Georg) Wirsinger, hudobný skladatel, ktorého tvorba sa zachovala tiež v tabulatúrnom zborníku sign. MUS A $3 .^{37}$ Spišské Podhradie (Kirchdrauf, Warallia) ako miesto pôsobenia Jána Šimráka st. (? - 1657) je po rokoch pre hudobnú historiografiu opätovne zaujímavé, kedže najnovšie genealogické bádania poukázali na úzke hudobné kontakty medzi týmto mestom a sliezskou metropolou Vroclav, kde pôsobil v Kostole sv. Alžbety ako organista hudobný skladatel' Ján Šimrák ml. (roky pôsobenia cca 1675 - 1692). ${ }^{38}$

Ako je to však s ostatnými mestami a mestečkami Spiša? Mnohé archívne informácie poukazujú na to, že aj v nich prebiehal zaujímavý hudobný život. Vieme, že Samuel Marckfelner, ktorý sa narodil v Košiciach, pôsobil pred príchodom do Levoče jeden rok v Spišských Vlachoch (Wallendorf). Hudba Jána Šimráka st. musela byt’ dobre známa nielen na Spiši, kde pôsobil, ale predvádzala sa aj v dalších evanjelických kantorátoch v Európe - v Šariši (Bardejov/Bartfeld/Bártfa, Prešov/Eperies), v stredoslovenských banských mestách (Hauerland), v Transylvánii (Sibiň/Sibiu/Hermannstadt) a tiež vo Vroclave (Wrocław/Breslau, Kostol sv. Márie Magdalény). V prípade Juraja Wirsingera je za jeho menom uvedené skratkou Carpon., čiže miesto pôsobenia Krupina (Carpona) na strednom Slovensku. Podobne bola dešifrácia topografických skratiek dôležitá aj pri identifikácii kežmarského skladatela a notára Thomasa Goslera;

chitektonické a umelecké pamiatky), tiež demografický, etnický, hospodársky a kultúrny vývoj mesta.

35 MATÚŠ, František: Samuel Marckfelner. Príspevok k poznaniu života a diela levočského organistu, hudobného skladatela a senátora. In: ŽIFČÁK, František (ed.): Z minulosti Spiša IX-X. Levoča : Spišský dejepisný spolok, 2002, s. 137-149. PETŐCZOVÁ, Janka: Samuel Marckfelner bin ich genandt. In: Musicologica Slovaca, roč. 2 (28), 2011, č. 1, s. 108-120.

36 PETÖCZOVÁ, Janka: Tomáš Gosler - neznámy spišský skladatel' 17. storočia. In: Slovenská hudba 21, 1995, č. 2, s. 228-262.

37 PETÖCZOVÁ-MATÚŠOVÁ, Janka (trans. a ed.): Georg Wirsinger / Juraj Wirsinger. Missa a 6. Tulerunt Dominum meum. 1640 (= Musica Scepusii Veteris IX/1). Bratislava : Ústav hudobnej vedy SAV; Prešov : Prešovský hudobný spolok Súzvuk, 2015.

38 PETÖCZOVÁ, Janka: Šimrák versus Šimbracký. Mythen und Realität in der slowakischen Musikhistoriographie. In: Hudební věda, roč. 52, 2015, č. 3-4, s. 273-316. 
skratky totiž označujú jeho pôvod aj povolanie - Flentsb. Holsat. Not: Caismar:, dosvedčujú teda, že pôsobil ako notár, a že sa narodil vo Flensburgu v regióne Šlezvicko-Holštajnsko (Schleswig-Holstein, od 19. storočia spolková krajina Nemeckého cisárstva). V domácich rukopisných prameňoch sa skratky použili zvyčajne na označovanie vel'mi známych, blízkych lokalít - napríklad v tabulatúrnych zborníkoch nájdeme za menom Jána Šimráka st. skratky „O. W.“ alebo „O: Vara:“, v ktorých sa „skrýva“ označenie pracovného postavenia - organista - a miesta pôsobenia - Spišské Podhradie (Kirchdrauf, Warallia).

Topografické skratky nie je vždy jednoduché dešifrovat', najmä ked’ sa týkajú vzdialenejších a menej známych lokalít - napríklad levočský organista Ján (Johann) Plotz, predchodca Samuela Marckfelnera, pripísal ku svojmu menu na prídoští tlačeného spevníka Johanna Vogela Psalmen Davids (1638) zachovaného v historickej knižnici


Plotz B S Anno 1645 Ad. 10. Sept: | Zu Leutsch p. T. Organista“. Z levočských archívnych dokumentov vieme, že Ján Plotz bol organistom vo farskom kostole v rokoch 1641 - 1648. Súčasne sa však v pol’ských hudobných prameňoch zachovala informácia o jeho pôsobení v sliezskom meste Breh (hist. Brieg, Brzeg PL), ktorá je uvedená v rukopisnom tabulatúrnom zborníku sign. Ms. mus. 40056 (PL-KJ) - "Johannes Plotz Vom Brieg | Caspar Plo(tz) organist | zu brieg in der PfarHer | Kirch". 39 To potvrdzuje hypotézu, že písmená v skratke „B S“ v spevníku Psalmen Davids za menom organistu Jána Plotza označujú jeho sliezsky pôvod Bregensis Silesius.

Ukazuje sa teda, že toponymá patria ku klúčovým slovám pri vyhodnocovaní hudobných prameňov. Umožňujú identifikáciu hudobníkov a podnecujú širší nadregionálny a transregionálny výskum. Z hladiska predmetu bádania si vyžaduje hudobnotopografický výskum Spiša zameranie sa na nasledujúce aktivity: I. výskum zachovaných hudobných prameňov, II. výskum zachovaných historických hudobných nástrojov, III. výskum zachovaných kroník, dobových tlačí a historických opisov Spiša, IV. výskum archívnych prameňov obsahujúcich sekundárne informácie o hudobnom živote, V. výskum zachovaných historických máp.

\section{Ad I. Hudobné pramene}

Základnú topografickú siet’ spišských miest tvoria lokality, v ktorých sa zachovali najstaršie hudobné pramene zo 16. a 17. storočia:

Levoča (Leutschau): Levočská evanjelická zbierka hudobnín (SK-Le, MUS A); ${ }^{40}$

39 KOCH, Klaus-Peter: Das Claviertabulaturbuch von Caspar und Johannes Plotz. Bemerkungen zu Samuel Scheidt anhand der wieder aufgefundenen Handschrift Mus. ms. 40056 der ehemaligen Preußischen Staatsbibliothek Berlin. In: Beiträge zur musikalischen Quellenforschung. Protokollband Nr. 2 der Kolloquien im Rahmen der Köstritzer Schütz-Tage 1988-1990. Bad Köstritz : Forschungs- und Gedenkstätte Heinrich-Schütz-Haus Bad Köstritz, 1991, s. 229-243.

40 MATÚŠ, František: Súpis hudobnín v knižnici Evanjelickej cirkvi a. v. v Levoči. 1. Historický hudobný fond (16. - 17. storočie); 2. Prehladný súpis d’alších hudobnín (18. - 20. storočie). Strojopis. Levoča; Prešov : UPJŠ v Prešove, 1974. HULKOVÁ, Marta: Levočská zbierka hudobnín. (2 zv.) Diss. Bratislava : FFUK, 1985, strojopis. PETŐCZOVÁ, Janka: Príspevok k aktuálnym výskumom hudobných prameňov od 18. storočia (MUS B) v Levočskej evanjelickej zbierke hu- 
Kežmarok (Kesmark): Učebnice hudby Leonarda Stöckela De Musica I a De Musica II (SK-KE, N 139, olim S 38956); ${ }^{41}$

Lubica (Leibitz): L'ubický spevník (SK-BRnm MUS XVIII 652), Kruczayho spevník (Lubica, dnes nezvestný, fotokópia SK-BRsav); ${ }^{42}$

Velká (Felka, dnes mestská čast Popradu): Gebeth nach der Summa Der Sonntag-Evangelien | M. Radaschinus, ad quem 1566; ${ }^{43}$ Himmlischer Engel-Schall oder Gesangbuch Mikuláša Simonidesa (Nicolaus Simonides 1685). ${ }^{44}$

V epoche neskorého baroka až klasicizmu dokážeme identifikovat širšiu topografickú siet spišských miest vd’aka zachovaným zbierkam hudobnín (resp. jednotlivým hudobninám), ktoré boli zvyčajne lokalizované na chóroch kostolov. Samotná ich prítomnost' neraz implicitne informuje o nadväznosti na kvalitnú hudobnú kultúru v danej lokalite už v predchádzajúcom storočí:

Gelnica (Gölnitz): Zbierka hudobnín rímskokatolíckeho farského kostola (Gelnica, Archív Rímskokatolíckeho farského kostola, sine sign.);

Kežmarok (Kesmark): Zbierka hudobnín rímskokatolíckeho farského kostola (SK-BRnm MUS IX); Zbierka hudobnín v Lyceálnej knižnici v Kežmarku (SK-KE);

Levoča (Leutschau): Zbierka hudobnín rímskokatolíckeho farského kostola (SK-L), Levočská evanjelická zbierka hudobnín (SK-Le, MUS B); ;5

Lubica (Leibitz): Zbierka hudobnín rímskokatolíckeho farského kostola (SK-BRnm MUS X);

Podolínec (Pudlein): Zbierka hudobnín piaristického kláštora z Podolínca (SK-MO, olim SK-J):46

Spišská Belá (Zipser Bela): Kirchen Gesangbuch | Beela (1753, SK-Le);

dobnín. In: Malé osobnosti velkých dejín - velké osobnosti malých dejín V. Príspevky k hudobnej regionalistike. Ed. Edita Bugalová. Bratislava : SHS; SNM-Hudobné múzeum, 2019, s. 108-118.

41 MATÚŠ, František: De Musica Leonardi Stöckelii. In: Slovenská hudba, roč. 17, 1991, č. 4, s. 360416. MATÚŠ, František: Príspevok k poznaniu vývinu hudobnoteoretického myslenia na Spiši v 16. storočí. In: Musicologica Slovaca et Europaea, roč. 19, 1994, s. 35-40.

42 HULKOVÁ, Marta: Lubický spevník. In: Musicologica Slovaca, roč. 12, 1988, s. 11-134. RUŠČIN, Peter: Repertoár Kruczayho spevníka v stredoeurópskom kontexte. In: Štýlotvorné prvky vo vokálnej a inštrumentálnej hudbe 16. - 18. storočia. Prešov : Súzvuk, 2002, s. 63-79. HULKOVÁ, Marta: Evangelische handschriftliche Gesangbücher aus der Spiš (Zips) von der Wende des 17. und 18. Jahrhundert. In: Die Gegenreformation und Barock in Mitteleuropa in der Slowakei. Ed. Ladislav Kačic. Bratislava : Slavistický kabinet SAV, 2000, s. 239-250.

43 Michal Radašín (Michael Radaschinus Liburnus, ca. 1510 - 1566) - prvý evanjelický farár v Bardejove, od r. 1544. PETÖCZOVÁ, Janka: Hudba ako kultúrny fenomén v dejinách Spiša. Raný novovek. Bratislava : Ústav hudobnej vedy SAV; Prešov : Prešovský hudobný spolok Súzvuk, 2014, s. 17.

44 RUŠČIN, Peter: Die Kirchenlieder aus dem handschriftlichen Gesangbuch Himmlischer Engel-Schall (1685) von Nicolaus Simonides. In: The Musical Sources of Spiš/Zips and Central Europe. Ed. Janka Petőczová. Bratislava : Ústav hudobnej vedy SAV, 2018, s. 60-95.

45 PETÖCZOVÁ, Janka: Musical Sources of the Levoča/Leutschau Lutheran Musical Collection from the Era of Dittersdorf, Haydn and Beethoven: Secular Music. In: Musical Analysis: Historia - Theoria - Praxis. Volume V. Eds. Anna Granat-Janki et al. Wrocław : The Karol Lipiński Academy of Music in Wrocław, 2019, s. 143-168.

46 SMOLAREK, Dariusz: Katalog tematyczny muzykaliów z klasztoru Pijarów w Podolińcu. Thematischer Katalog für Musikalien aus dem Piaristen-Kloster in Pudlein. Lublin : Wydawnictvo KUL, 2009. 
Spišská Kapitula (Zipser Kapitul): Zbierka hudobnín katedrálneho kostola (Knižnica Spišskej Kapituly);

Spišská Nová Ves (Neudorf, Igló): Zbierka hudobnín rímskokatolíckeho farského kostola (Spišská Nová Ves, Chór rímskokatolíckeho farského kostola, torzo, sine sign.);

Spišské Podhradie (Kirchdrauf, Warallia): Zbierka hudobnín rímskokatolíckeho farského kostola (SK-BRnm MUS XI);

Smolnícka Huta (Schmölnitzhütte): Zbierka hudobnín rímskokatolíckeho farského kostola (Smolnícka Huta, Chór rímskokatolíckeho farského kostola, sign. H 1-112), Spevník zo Smolníckej Huty (SK-BRnm MUS I 354);

Smolník (Schmölnitz): Zbierka hudobnín rímskokatolíckeho farského kostola (SK-BRnm MUS XXIII); ${ }^{47}$

Švedlár (Schwedler): Zbierka hudobnín rímskokatolíckeho farského kostola (SK-BRnm MUS XX). ${ }^{48}$

Pri vytváraní hudobnotopografickej siete spišských miest musíme brat’ do úvahy aj lokality, na ktoré odkazujú toponymá zapísané v rukopisných prameňoch súvisiacich s dejinami hudby na Spiši:

1) toponymá môžu odkazovat na prameň, ktorý sa zachoval in situ, čím potvrdzujú predvádzanie hudobného repertoáru v danej lokalite, napríklad poznámka Leitschau v levočskom rukopisnom hlasovom zošite partu Altus secundi chori na vnútornej časti obalu (SK-Le MUS A 55, olim 13996) poukazuje na predvádzanie polychorickej hudby v Levoči. V tomto prípade potvrdzuje afiliáciu k Spišu aj použitý papier vyrobený v Spišskej Teplici v roku 1648. ${ }^{49}$ Za vel’mi vzácne sa považujú toponymá, ktoré umožňujú identifikovat’ migráciu hudobníka žijúceho na Spiši na základe zápisov iných miest jeho pôsobenia. Príkladom môžu byt autografné zápisy Samuela Marckfelnera v levočskom tabulatúrnom zborníku sign. MUS A 5, olim 13994); poukazujú jednak na hudbu predvádzanú v mieste jeho pôsobenia a zachovanú in situ - Levoča (zápis Leützsch, f. 9v), jednak na hudbu predvádzanú na miestach jeho peregrinácií v Sedmohradsku (zápisy Gemacht ihm Jahr 1.6.4.8. den 20 Sontag Trinit. Von Sa: Mar: zu Schössburg ihn Siebenbürgen, f. 27' wie man zu Krohn in Siebebürgen pflegt zu süngen, f. $77^{\mathrm{r}}$, Anno Domini 1643 Corona, f. 142 ${ }^{\mathrm{r}}$ ); ide o mestá dnešného Rumunska Braşov a Sighişoara (Braşov/Kronstadt/Corona; Sighişoara/Schäßburg/Schössburg), v ktorých Marckfelner pôsobil pred príchodom do Levoče medzi rokmi 1643 a 1648;

47 BURGROVÁ, Katarína: Záchrana a zachovanie hudobnokultúrneho dedičstva Smolníka a Smolníckej Huty na východnom Slovensku ako jedna z významných hudobných aktivít Prešovského hudobného spolku Súzvuk. In: Súzvuk 1. Aktivity členov Prešovského hudobného spolku Súzvuk v rokoch 2001 - 2002. Ed. František Matúš. Prešov : Súzvuk, 2003, s. 31-35. BURGROVÁ, Katarína: Hudobnohistorické pramene zo Smolníckej Huty. Anonymná hudobná tvorba a jej identifikácia. In: Ad honorem Richard Rybarič. Ed. Janka Petőczová. Bratislava : Ústav hudobnej vedy SAV, 2011, s. 85-95.

48 Uvedené zbierky hudobnín s afiliáciou SK-BRnm pozri: KALINAYOVÁ-BARTOVÁ, Ref. 5. DAS LEHOTSKÁ, Ref. 5.

49 HULKOVÁ, Marta: Rukopisné hlasové zošity Levočskej zbierky hudobnín (17. storočie). In: Slovenská hudba, roč. 21, 1995, č. 2, s. 210. 
2) toponymá môžu odkazovat' na prameň, ktorý sa nezachoval in situ, ale migroval v rámci regiónu, napríklad v Levočskej evanjelickej zbierke hudobnín sa zachoval spevník Kirchen Gesangbuch | Beela | Anno Christi 1753, ktorý vznikol pre potreby Spišskej Belej, a ktorý podla zápisu na titulnom liste vyhotovil Thomas Dreypfennig. Titulný list teda poskytuje informáciu, že Dreypfennig bol v roku 1753 kantorom evanjelickej cirkvi v Spišskej Belej. Vieme o ňom tiež, že od 1777 bol rektorom tamojšej evanjelickej školy. ${ }^{50}$ Je zaujímavé pátrat po migrácii tohto prameňa do Levoče. Pri komparácii dejín obidvoch cirkevných zborov zistujeme, že jeden z levočských evanjelických farárov - Johann Weiß (Weisz) pôsobil v rokoch 1754 až 1760 pred príchodom do Levoče v Spišskej Belej. ${ }^{51}$ Pravdepodobne práve on mohol iniciovat' vznik spevníka na predchádzajúcom pôsobisku a po prestahovaní sa do Levoče (1760) si ho mohol zobrat’ na svoje nové pôsobisko. Táto úvaha ostáva však v rovine hypotézy dovtedy, kým ju dokážeme potvrdit hodnovernými údajmi z prameňov;

3) toponymá môžu odkazovat na prameň, ktorý používali viacerí ludia a vo viacerých lokalitách, pri spišských hudobninách ide zvyčajne o stredoeurópsky hudobnokultúrny priestor. Typické je to pre konvolúty obsahujúce viaceré jednotky, napríklad Konvolút sign. N 139 (olim S 38956) z druhej polovice 16. storočia, ktorý sa nachádza v Lyceálnej knižnici v Kežmarku, obsahuje 21 rukopisných a tlačených jednotiek, medzi nimi tri rukopisné učebnice hudby a matematiky od Leonarda Stöckela (1510 - 1560) - Arithmetica, De Musica I a De Musica II, a tiež Stöckelove d’alšie úvahy o hudbe, napríklad Argumenta de Musica canenda et discenda [Argumenty o potrebe spievat' a učit’ sa hudbu] a Quare decreverim redire ad Musicam [Prečo som sa rozhodol vrátit’ k hudbe]. Vieme, že odpisy Stöckelových učebníc vyhotovil v roku 1567 rektor školy v Spišskej Belej Ján (Johannes) Fabri, ktorý žil (resp. študoval) predtým v Zhorelci (Görlitz/Zgorzelec, Sliezsko, dnes mesto rozdelené hranicou medzi Nemeckom a Pol'skom), čo je uvedené na vnútornej strane obalu konvolútu. Na tej istej strane sa v marginálnej poznámke - Johannes Scholtz hunc possidet Libellum - nachádza aj meno d’alšieho identifikovaného vlastníka Jána Scholtza (Johannes, ? - 1593). Scholtz bol v poradí druhým evanjelickým farárom v Spišskej Belej. Prvým bol známy zakladatel’ a šíritel’ reformácie na Spiši Vavrinec Serpilius Quendel (Laurentius Serplius Quendelius, ? - 1572). Scholtz prišiel do Spišskej Belej v roku 1559 po predchádzajúcom pôsobení vo Vrbove a v Lubovni. Quendel odišiel v tomto roku zo Spišskej Belej na post farára do Levoče, neskôr pôsobil v Lubici a zomrel v Spišskej Sobote. Jednotlivé rukopisné a tlačené jednotky Konvolút sign. N 139 mali teda dostatok „možností migrovat spolu so svojimi rôznymi majitel'mi. Hlavné vlastníctvo prameňa je však možné pripísat Jánovi Fabrimu, ktorého posesorský záznam je aj na prídoští - Iohannes fabri possidet. Fabriho rukopisné odpisy Stöckelových traktátov sú výnimočné tým, že na

50 Činnoste školy v Spišskej Belej bola v r. 1777 obnovená po vyše sto rokoch obdobia rekatolizácie, počas ktorej bola jej existencia zakázaná. MALOVCOVÂ, Božena: Školstvo v Spišskej Belej do roku 1918. Evanjelické školstvo. In: Spišská Belá. Ed. Zuzana Kollárová. Prešov : Universum, 2006, s. 143.

51 Božena MALOVCOVÁ: Náboženské pomery do roku 1918. Evanjelická cirkev a. v. In: Spišská Belá. Ed. Zuzana Kollárová. Prešov : Universum, 2006, s. 125. 
základe topografických údajov v nich dokážeme datovat cestu tohto mladého vzdelanca zo zahraničia na Spiš; začiatkom roka 1566 bol ešte v Zhorelci (január, február) a v roku 1567 už zhotovoval odpisy Stöckelových učebníc v Spišskej Belej. Z d’alších jednotiek, ktoré sú súčastou Konvolútu sign. N 139, si Ján Fabri mohol zo Zhorelca priniest' aj dve tlače vydané v tomto meste v roku 1566 Inicia Doctrinae Arithmeticae olim a Glareano Tradita Henricha Loritiho Glareana (1488 - 1563) a De Civilitate Morvm pverilium libellvs Desideria Erasma Rotterdamského (1467 - 1536). Nie je vylúčené, že aj ostatné tlače v konvolúte mohli tvorit’ jeho študijnú, a teda aj budúcu pedagogickú (resp. teologickú) výbavu, ktorú získal v Sliezsku - Arithmeticae Practicae Methodus Facilis Rainera Gemma (Wittenberg 1561), Musica Nicolai Listenii Mikuláša Listenia (Wittenberg 1552), Compendiolvm Mvsicae Pro Incipientibvs Henricha Fabera (Frankfurt nad Odrou 1548), Brevissima Rudimenta Musicae pro Incipientibus (s. 1., s. d., s. n.) Mikuláša Listenia a Trost der Eltern wenn ire Kinder kranck werden vnd im HERRN entschlaffen Georga Walchera (Wittenberg 1559). ${ }^{52}$ Navyše, v Zhorelci Ján Fabri ešte aj odpísal Listeniovu učebnicu hudby, je teda zrejmé, že tam mal možnost’ zoznámit’ sa v praxi s vyučovaním hudby, s hudobným repertoárom, aj s reformou tamojšieho rektora školy Petra Vincentia (1519 - 1581), ktorá predpokladala existenciu dvoch speváckych zborov: jeden, zložený z chudobných žiakov, sprevádzal liturgiu chorálnou hudbou, druhý - Chorus symphoniacus - sa zúčastňoval na predvádzaní umeleckej figurálnej hudby pre bohoslužby. Tieto skúsenosti potom mohol Fabri aplikovat’ vo vlastnej praxi na Spiši. Konvolút sign. N 139 sa neskôr používal nielen v Spišskej Belej, resp. v Kežmarku, ale napríklad aj v škole v Levoči, o čom svedčí poznámka Leütsch 1578 zapísaná za rukopisnou statou „Amor Docet Musicam“. Ide tu o krátke vysvetlenie svetskej témy spojenia inšpiratívnej sily hudby a poézie - „Láska učí spievat", resp. „Láska učí muzicírovat“" ${ }^{53}$ Táto téma bola v dejinách známa napríklad aj z vyobrazenia amorka (Cupida) držiaceho lutnu na embléme s distichonom z roku 1611 Gabriela Rollenhagena $(1583-1618) ; ;^{54}$

4) toponymá môžu označovat’ miesta odpisu hudby, čo je už spomenutý prípad odpisovania skladieb do tabulatúrnych zborníkov, ktoré vznikli postupným prirad’ovaním jednotlivých papierových hárkov do väčšieho celku; najpočetnejšie sú uvedené miesta odpisu hudby Jána Šimráka st. v levočskom zborníku sign. MUS A 3 - Lubica, Spišské Podhradie, Smolník, Banská Štiavnica (Schemnitz) a Nitrianske Pravno (Teutoprona, Deutschproben). Toponymá nájdeme v tomto zborníku aj pri iných dielach, napríklad za šesthlasnou polyfonickou skladbou Thomasa Goslera

52 PETÖCZOVÁ, Janka: Leonard Stöckel a hudba. In: Leonard Stöckel a reformácia v strednej Európe (= Acta Collegii Evangelici Prešoviensis XI). Ed. Peter Kónya. Prešov : Vydavatel'stvo Prešovskej univerzity v Prešove, 2011, s. 70-84.

53 Liebe lehrt singen (č. 525); Liebe lehrt Lautenschlagen (č. 528). WANDER, Karl Friedrich Wilhelm: Deutsches Sprichwörter-Lexikon; Ein Hausschatz für das Deutsche Volk; Vol. 3, 1873, s. 151152. Reprint Darmstadt : Wissenschaftliche Buchgesellschaft, 1977.

54 Amor docet musicam. Musik und Liebe in der frühen Neuzeit (= Studien und Materialien zur Musikwissenschaft 67). Eds. Dietrich Helms, Sabine Meine. Hildesheim : Georg Olms Verlag, 2012. Vyobrazenie emblému dostupné na internete: http://distichalatina.blogspot.com/2012/03/ amor-docet-musicam.html. 
Du hast mir das Herz genommen sa nachádza poznámka, že bola odpísaná 23. júna 1642 v Lubici (Leibicii Ispa Vigilia Joh. Bapt.) (sign. MUS A 3, f. 153v);

5) toponymá sú zaujímavé aj z iných hladísk, vo vtedajšej dobe boli totiž jedným zo spôsobov (seba)identifikácie a vzdelanci si ich uvádzali za menom vo forme rôznych skratiek, pričom mohlo íst' o lokalitu pôvodu, miesto pôsobenia alebo geograficky širšie územie; napríklad kežmarský rektor školy Dávid (David) Praetorius

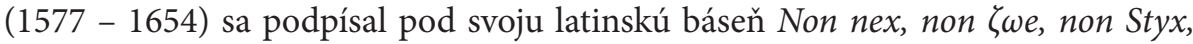
non mundus et ulla Vis, non sejunget nos ab amore DEi [Ani smrt', ani život, ani podsvetná rieka Styx, ani svet, ani nijaká sila nás neodlúči od Božej lásky] skratkou „M. D. Praet.|alaus Zipser“, čiže „tunajší Spišiak“ (sign. MUS A 3, f. 275²) (Obr. 1). Báseň sa nachádza pod notovým zápisom v strede dvojzborovej skladby Thomasa Goslera Ist Gott für uns, wer mag wider uns sein? na volnom mieste papierových hárkov a je dôkazom, že bola napísaná priamo „na mieru“; je totiž venovaná skladatelovi, ospevuje jeho hudbu a pozitívne hodnotí jeho rozhodnutie zhudobnit’ biblické myšlienky z listu apoštola Pavla Rímskym. ${ }^{55}$ Táto symbióza básne a zápisu hudobného diela vôbec nie je v tabulatúrnych rukopisoch bežným javom. V tomto prípade ide o vzácne dobové svedectvo situácie v evanjelickom mestskom kantoráte v Kežmarku, v ktorej rektor mestskej školy Dávid Praetorius rovnako ako mestský notár Thomas Gosler disponovali kvalitným hudobným vzdelaním; obaja žili a pracovali v priatel'skej atmosfére v kruhu viacerých evanjelických vzdelancov. Praetorius bol nielen dlhoročným učitel’om (od roku 1608), ale aj mimoriadne váženou osobnostou. ${ }^{56}$ Jeho žiakom bol vynikajúci matematik a polyhistor Dávid (David) Frölich (1595 - 1648), práve ten, ktorý upozornil v roku 1639 vo svojej tlači Medulla geographiae practice [Jadro praktického zemepisu] na existenciu hudobnej spoločnosti Collegium Musicum v Spišskej Novej Vsi. ${ }^{57}$

\section{Ad II. Historické hudobné nástroje, organy}

Druhý typ hudobnotopografickej siete spišských miest tvoria tie lokality, v ktorých vieme sledovat' historické hudobné nástroje, najčastejšie organy, bud' ako kompletné nástroje, alebo aspoň čiastočne zachované na chóroch kostoloch. Pri ich výskume je základnou „studnicou“ poznatkov publikácia Otmara Gergelyiho a Karola Wurma Historické organy na Slovensku (1982), v ktorej sú zdokumentované organy v kostoloch na Spiši; rozdelené sú chronologicky, podla ich genézy vo vývine hudobných štýlov: 1) Z konca renesancie a $z$ obdobia raného baroka sa na Slovensku zachovalo trinást’ organov, z nich osem sa nachádza na Spiši, v mestách Levoča (2 organy), Kežmarok, Spišská Belá, Spišská Stará Ves, Huncovce (okres Kežmarok), Spišská Sobota (dnes

55 PETÖCZOVÁ, Ref. 43, s. 180-182.

56 REZIK, Ján - MATTHAEIDES, Samuel: Gymnaziológia. Dejiny gymnázií na Slovensku. Bratislava : Slovenské pedagogické nakladatel'stvo, 1971, s. 320.

57 PETŐCZOVÁ, Ref. 43, s. 99. FRÖHLICH, David: Medulla geographiae practicae. Bardejov : 1639, s. 348-355. Dostupné na internete: https://books.google.sk/books?id=ER1RUpueYQgC\&print$\mathrm{sec}=$ frontcover\&dq=medulla+geographiae + practicae $\& \mathrm{hl}=\mathrm{sk} \& \mathrm{sa}=\mathrm{X} \& v e d=2 \mathrm{ahUKEwjk643Zl}-$ tfsAhUFrxoKHTRaBJwQ6AEwAnoECAMQAg\#v=onepage\&q=medulla\%20geographiae $\% 20$ practicae $\& \mathrm{f}=$ false. 
mestská čast’ Popradu), Žakovce (okres Kežmarok); ${ }^{58}$ 2) Z obdobia vrcholného baroka sa na Slovensku zachovalo dvadsatjeden organov, z nich tri sa nachádzajú na Spiši v mestách: Levoča, Kežmarok, Iliašovce (okres Spišská Nová Ves); ${ }^{59} 3$ ) Z obdobia neskorého baroka a klasicizmu sa na Slovensku zachovalo dvadsatdevät’ organov, z nich štyri sa nachádzajú na Spiši v mestách: Švedlár (okres Gelnica), Štôla (okres Poprad), Gelnica, Hrabušice (okres Spišská Nová Ves). K nim môžeme ešte pripočítat organ v Matejovciach (dnes mestská čast’ Popradu) vybudovaný začiatkom 19. storočia. ${ }^{60}$ Spolu je to teda trinást' historických miest na Spiši, v ktorých sa zachovali originálne organy, pričom je potrebné podčiarknut', že v prípade najstarších nástrojov - organov z obdobia raného novoveku - je región Spiša z celoslovenského hladiska regiónom $s$ najväčším množstvom takýchto zachovaných nástrojov. ${ }^{61}$

Každý z týchto nástrojov je potrebné posudzovat samostatne, pretože aj organy mohli „migrovat“; ich detailný výskum teda môže priniest̉ nové poznatky aj k iným lokalitám, než v ktorých sa nachádzajú v súčasnosti. Napríklad v Huncovciach sa nachádza organ s pôvodnou drevenou skriňou (nástroj bol renovovaný a doplnený novými píštalami v 20. storočí), na ktorej sa našiel nápis „Samuel Stascovius A D 1653“; tento organár (rezbár) nie je identifikovaný, vieme len, že podla farskej kroniky bol organ kúpený zo Spišskej Novej Vsi v roku 1792. Navyše, presne taká istá organová skriňa sa nachádza v rímskokatolíckom kostole vo Velkej (dnes mestská čast’ Popradu). ${ }^{62}$ Výskum nástrojov a nástrojárov musí teda zahŕňat detailné bádanie v celej vytypovanej lokalite, v tomto prípade na celom Spiši.

Napokon samotný výskum nástrojárov - stavitelov organov - poskytuje širokú škálu možností sledovat hudobnotopografické kontexty; spomeňme aspoň organárov žijúcich v 18. storočí v Levoči. Levočský organár Ján Antel (Johann Antl), ktorého evidujeme v meste od 26. novembra 1708, ked' sa stal levočským meštanom, opravoval napríklad v uvedenom roku aj organ v Bardejove. ${ }^{63}$ Ďalší chýrny organár Vavrinec Čajkovský (Laurentius Czeukowsky, Lorenz Cseikovsky 1677 - 1749), kremnický rodák, ktorý v Levoči získal mestské právo v roku 1714, staval organy v Kežmarku, Velkom Slavkove a v Šoprone. ${ }^{64} \mathrm{~V}$ tom období bola Levoča centrom hudobného nástrojárstva v Spišskej stolici. Niektorí nástrojári boli evidovaní ako riadni levočskí meštania, iní

58 GERGELYI, Otmar - WURM, Karol: Historické organy na Slovensku. Bratislava : OPUS, 1982, kapitola „Dozvuky renesancie a raný barok“, s. 86.

59 GERGELYI - WURM, Ref. 58, kapitola „Vrcholný barok“, s. 87-149.

60 GERGELYI - WURM, Ref. 58, kapitola „Neskorý barok a klasicizmus“, s. 151-270.

${ }_{61}$ Z novšej literatúry k dejinám organov pozri: KLINDA, Ferdinand: Organ v kultúre dvoch tisícročí. Bratislava : Hudobné centrum, 2000. MAYER, Marian Alojz: Dejiny organa na Slovensku od najstarších čias po súčasnost'. Bratislava : Divis-Slovakia s.r.o., 2009. Projekt Organy a organári na Slovensku 1651 - 2006 autorov Mareka Cepka a Mariana Alojza Mayera [DVD], (Bratislava : Hudobné centrum, 2012), zahŕňa opis organov v hraniciach súčasného administratívneho členenia Slovenska, a to v ôsmich krajoch (Banskobystrický, Bratislavský, Košický, Nitriansky, Prešovský, Trenčiansky, Trnavský, Žilinský). Dostupné na internete: http://organy.hc.sk/web/index.php.

62 GERGELYI - WURM, Ref. 58, kapitola „Vrcholný barok“, s. 55.

63 Štátny archív v Prešove, Špecializované pracovisko Spišský archív v Levoči (dalej: Spišský archív v Levoči), Magistrát mesta Levoča (MML), XXI/15, Acta et Fragmenta Prothocollaria 1708, 1709, s. 444.

${ }^{64}$ SZÓRÁDOVÁ, Eva: Historické klavíry na Slovensku (Klavichordy, čembalá, kladivkové klavíry). Bratislava : Scriptorium Musicum, 2004, s. 20-21. 
pracovali v meste len prechodne v organárskych dielňach. Spravidla však výrobcovia organov cestovali za prácou. $V$ mieste, kde mali dielňu, zhotovovali organové píštaly a potrebné diely na výstavbu nástroja, ale montovali ich na mieste stavby organa. V Levoči sa vyrábali okrem organov a pozitívov aj iné klávesové nástroje (klavichordy, čembalá, neskôr klavíry a harmóniá). Jedným z najvýznamnejších organárov, ktorých pôsobenie bolo spojené aj s Levočou, bol rodák z Turca František Eduard Pecník (Franciscus Eduardus Petznik, Pecznik, Pecsnik 1748 - 1815). Tento organár sa po rokoch štúdií v Banskej Bystrici (1762 - 1765) a v Šoprone (1770) a po rokoch peregrinácí́ (Viedeň, Augsburg, Metz, Nancy, Paríž, Amsterdam, Londýn, etc.) vrátil v roku 1781 do Uhorska a našiel si prácu v Levoči u spišského rodáka, organára Jozefa Boroveckého (Josephus Borovetzky, Boroveczky, Borroveczky, 1744 - po 1798). Neskôr pät rokov pracovali spolu v Prešove a potom si Pecník otvoril v roku 1787 v Levoči svoju vlastnú dielňu. Prvým samostatným dielom Eduarda Pecníka bol pozitív v Evanjelickom a. v. kostole v Poprade-Strážach (1788), nástroj, ktorý sa dnes nachádza v Kostole klarisiek v Bratislave. V nasledujúcich rokoch František Eduard Pecník zúročil svoje bohaté vedomosti $z$ vandrovky $v$ rôznych mestách; pracoval v Prešove, Bardejove a Tisovci, spolu postavil dvadsat organov v rôznych mestách Uhorska. Unikátne sú jeho pozitívy, z ktorých sa osem zachovalo v Gemeri (napríklad v Lipovci a v Drienčanoch). Spišsko-gemerské kontakty $\mathrm{v}$ organárstve reprezentuje v nasledujúcom storočí levočský nástrojár Andrej (Andreas) Zimmer (1800 - 1857), ktorý v postavil šestregistrový organový pozitív v Kostole Zvestovania Panny Márie v Chyžnom. ${ }^{65}$

Ak bádanie rozšrírime aj o oblast výroby klavírov a klávesových nástrojov, potom od konca 18. storočia môžeme do skúmanej hudobnotopografickej siete Spiša priradit dalšie lokality: historické mestečko Vrbov (Menhardsdorf, dnes obec, okres Kežmarok), kde Jakub Roth vyrábal klavíry a klavichordy, a tiež Spišskú Sobotu (Georgenberg, dnes mestská čast Popradu), kde pracovali Daniel a Ján Dávid Valachyovci, profesionálna rodina nástrojárov. ${ }^{66}$ Všetky tieto lokality so zachovanými (resp. čiastočne zachovanými) historickými hudobnými nástrojmi dokumentujú pestovanie polyfonickej (figurálnej) hudby na Spiši, pričom rozsah obsadenia pri predvádzaní môžeme čiastočne dedukovat $\mathrm{z}$ počtu zachovaných registrov organov. V prípade nástrojov zachovaných z obdobia neskorého baroka a klasicizmu je potrebné upozornit' na opatrnost pri vyhodnocovaní lokality a na väzby organa na konkrétny (historický) kostol, kedže do úvahy je nevyhnutné brat čas výstavby (renovácie) kostolov a ich konfesionálne premeny (evanjelická, katolícka príslušnost'). Dokonca mohol nastat aj prí-

65 A. Zimmer pracoval od roku 1836 v Spišskej Novej Vsi, od roku 1838 v Levoči. ŠTAFURA, Andrej: Historické organy stredného Gemera. Dejiny a dispozícia organov. Revúca : Quirinus, 2016, s. 36, 68. MAYER, Marian Alojz: Slovenský organár František Eduard Pecník. In: Slovenská hudba, roč. 25, 1999, č. 2-3, s. 361, 382. GERGELYI - WURM, Ref. 58, s. 221, 222, 226.

${ }_{66}$ V Národnom múzeu v Krakove (Muzeum Narodowe w Krakowie, Sign. 77.815) sa nachádza jeden klavichord Daniela Valachyho vyrobený v roku 1780. Od Jána Dávida Valachyho (Johann David Wallachy, 1769 - 1818), syna Daniela Valachyho, sa zachoval klavichord vyrobený v roku 1804; dnes je zapožičaný Múzeu Spiša v Spišskej Novej Vsi (majetok Východoslovenského múzea v Košiciach) a nachádza sa v expozícii v letohrádku Dardanely v Markušovciach. SZÓRÁDOVÁ, Ref. 64, s. 21, 86, 87. KICZKOVÁ, Bernadeta: Letohrádok Dardanely - Expozícia klávesových hudobných nástrojov. In: Múzeum Spiša v Spišskej Novej Vsi, 1951 - 2011. Ed. Zuzana Krempaská. Spišská Nová Ves : Múzeum Spiša v Spišskej Novej Vsi, 2011, s. 43. 
pad, že pôvodný dvojlod’ový kostol bol nahradený úplne novým kostolom. Napríklad v spomínanom Spišskom Podhradí, kde pôsobil v 17. storočí ako evanjelický organista nemeckého farského kostola Ján Šimrák st., renovovali v nasledujúcom 18. storočí zničenú budovu farského kostola noví majitelia-katolíci, avšak v 19. storočí bol kostol po zemetrasení a povodni úplne zbúraný a nahradený novou, jednolodovou stavbou (dnes rímskokatolícky Kostol Narodenia Panny Márie).

Osobitnou kapitolou je výstavba nových evanjelických kostolov koncom 18. storočia po prijatí Tolerančného patentu $\mathrm{v}$ Uhorsku; toto je prípad organa $\mathrm{v}$ spomínaných Matejovciach (Matzdorf). V tomto historickom mestečku pri Poprade ukončili výstavbu nového tolerančného kostola v roku 1787 a organ do neho zhotovoval v rokoch 1806 - 1812 Michal Podkonický, ktorý však v roku 1816 zomrel a jeho prácu dokončil v roku 1823 viedenský organár Friedrich Deutschmann. ${ }^{67}$ Ten je zhotovitelom aj dvojmanuálového organa evanjelického tolerančného kostola v Spišskej Novej Vsi. Ak teda uvažujeme o hudobnom živote evanjelickej cirkevnej obce v Matejovciach v 17. storočí, musíme uvažovat’ o dnešnom rímskokatolíckom farskom Kostole sv. Štefana, ktorý bol v dejinách vyše jedno storočie evanjelický. Tento pôvodne gotický jednolodový kostol bol v 18. storočí zbarokizovaný a západnú stranu lode tvorí dnes murovaný luisézny organový chór. V každom prípade výstavba kvalitného organa v novom, tolerančnom evanjelickom kostole v Matejovciach Michalom Podkonickým a Friedrichom Deutschmannom indikuje velmi silnú tradíciu hudobného života v kultúrnom prostredí lokality, a to v obidvoch konfesiách. Ak teda poznáme históriu kostolov a hudobnotopografické súvislosti, potom lepšie porozumieme aj správe evanjelického farára a známeho spišského vzdelanca Juraja (Georg) Buchholtza st. (1643 - 1725) z roku 1664, ktorý vyzdvihoval vysokú úroveň vyučovania v škole v Matejovciach, pričom uviedol, že „chór bol v kostole uspôsobený tak, a hudba bola zostavená tak, že šestnást'- i viachlasnú skladbu bolo možné vokálne aj inštrumentálne predviest’ dvoj-, ba v mimoriadne sviatočné dni aj trojzborovo, kedže medzi obyvatelmi bolo 6 - 7 osôb, ktoré hudbe celkom dobre rozumeli“ ${ }^{68}$

V tomto prípade ide o vzácnu, jedinú priamu správu o pestovaní polychorickej hudby na Spiši a zároveň aj o svedectvo, že polychorická hudba sa tu pestovala v porovnaní so strednou Európou velmi dlho, a to aj v jednolodových kostoloch. Vokálno-inštrumentálna hudba sa pestovala v evanjelických spišských kantorátoch ešte aj tesne pred násilnou rekatolizáciou. Tu sa opät môžeme opriet’ o svedectvo farára Juraja Buchholtza st., ktorý uviedol vo svojom životopise zaujímavé spomienky zo svojho prvého skúšobného účinkovania na poste farára v Spišskej Sobote 31. mája 1671: „habe ich der Kirche meine Sing-Probe gethan, allso wir vocaliter und instrumentaliter mit Posaunen und Geigen musiciret haben: HE. XIII. Städten Graf Olmützer Organista ordinarius schlug selbsten die orgel (ein schön und großes neues Werk) wie er sonsten ein berühmter und lieblicher Orgel-schläger gewest, also hat er auch jetzund

67 GERGELYI - WURM, Ref. 58, s. 288.

68 LIPTAK, Johann - STEINECKER, Rolland: Das deutsche evangelische Schulwesen in der Slowakei (= Schriftenreihe des Hilfskomitees für die Ev.-Luth. Slowakeideutschen). Stuttgart : Hilfskomitee für die Evang.-Luth. Slowakeideutschen, 1957, s. 11. 
seinen besten Fleiß bey dem musiciren angewendet.“ ${ }^{69}$ Svedectvo vzniklo len niekolko rokov po ukončení výstavby nového organa (1663) vo vtedy evanjelickom farskom kostole (dnes rímskokatolícky Kostol sv. Juraja); 14-registrový dvojmanuálový organ sa $\mathrm{v}$ tom čase nachádzal nad sakristiou, lebo na dnešné miesto na západnej empore ho preniesli v roku 1678. Zhotovil ho organár polského pôvodu Tomáš Dobkowicz (Tomasz Dobkowitz, zom. 1667 v Kežmarku) a majstrovskú figurálnu výzdobu vyhotovil miestny rezbár Pavel Gross. ${ }^{70}$ Uvedené svedectvo navyše dokumentuje nielen existenciu kvalitného organa vo farskom kostole, ale aj skutočnost', že samotný gróf Ján (Johann) Olmützer, predstavitel' Provincie 13 spišských miest zálohovaných Polsku, bol dobrým organistom a hudobníkom, ktorý sa angažoval pri predvádzaní polyfonickej hudby v evanjelickom mestskom kantoráte v Spišskej Sobote.

\section{Ad III. Kroniky, dobové tlače a historické opisy Spiša}

Tretiu dôležitú skupinu zachovaných prameňov, ktoré musíme brat' do úvahy pri zostavovaní hudobnotopografickej siete spišských miest, tvoria kroniky, dobové tlače a historické opisy Spiša. Z 15. až 17. storočia sa zachovalo na Spiši osem kroník $;^{71}$ niektoré fragmentárne, iné z kratšieho časového obdobia, napríklad Kronika Konráda Spervogla 1515 - 1537 alebo Kronika Daniela Türcka 1548 - 1559. Jedna z kroník - známa Kronika Gašpara Haina (Caspar Hain) - zachytáva udalosti skoro dvoch storočí. Jej autor bol významnou osobnostou v dejinách evanjelickej cirkvi v Levoči; bol to rektor mestskej školy (v rokoch 1658 - 1664) a neskôr richtár (v rokoch 1682 - 1683) tohto slobodného královského mesta. ${ }^{72} \mathrm{~V}$ jeho kronike sa nachádza mnoho informácií o hudobnej kultúre a starší výskum dejín hudby v Levoči bol postavený prakticky len na informáciách z tejto kroniky (akademické Dejiny slovenskej hudby, 1957). Až v 80. rokoch minulého storočia doplnil tieto poznatky František Matúš hĺbkovým výskumom primárnych i sekundárnych hudobných prameňov. ${ }^{73}$ Dodnes však ostáva Kronika Gašpara Haina dôležitým prameňom predovšetkým pre poznanie hudobných osobností a sociálneho postavenia hudobníkov. Nájdeme tu zaznamenané výmeny na postoch kantorov a organistov, konkrétne udalosti v Levoči sprevádzané hudbou, napríklad pri oslave storočnice reformácie alebo pri príležitosti inštalácie nových farárov. Nachádza sa tu i detailný opis výstavby levočského organa vo farskom kostole v evanjelických časoch. Tento organ začal budovat Ján (Johann) Hummel a dokončil ho Juraj (Georg) Nitrovský. Hain podal aj opis problémov s organárom Hummelom, ktoré vyvrcholili v roku 1628: „Minulý týždeň došlo k prudkým hádkam s naničhodným opilcom z No-

69 Dejiny slovenskej hudby. Bratislava : Vydavatel'stvo SAV, 1957, kapitola „Rozvoj duchovnej piesne a inštrumentálnej hudby v 16. a 17. storočí, podkapitola: „Ladislav Mokrý: Hudba v školách“, s. 80 .

70 GERGELYI - WURM, Ref. 58, s. 57. Výzdoba organa pozri Musicon, dostupné na internete: http://www.musicon.sk/index.php?option=com_content\&view=article\&id=45\&Itemid=62.

71 PIIRAINEN, Ilpo, Tapani - POLLÁKOVÁ, Soňa: Die Chroniken der Frühen Neuzeit aus der Zips. Levoča : Spišský dejepisný spolok Levoča, 2013.

72 CHALUPECKÝ, Ivan: Kroniky a kronikári mesta Levoča. In: Pohlady do minulosti. Zborník prednášok z histórie I. Ed. Mária Novotná. Levoča : SNM - Spišské múzeum v Levoči, s. 25-37.

73 MATÚŠ, Ref. 25. 
rimbergu Hansom Hummelom, ktorý už štyri roky pretahuje stavbu organa, pričom minul dvojnásobok dohodnutej odmeny, a predsa organ nedokončil“. Hummelovi napokon hrozil súd. Ten sa však nekonal, lebo organár skončil tragicky, pádom z lešenia, a kronikár v druhej správe už len stručne poznamenal: „Zomrel bezbožný muž Hans Hummel, ktorého bez svetiel a bez kríža pochovali na cintoríne pri novom kláštore“" ${ }^{4}$ Takýto spôsob referencie nikoho nenecháva na pochybách, že výstavba organa ležala Levočanom na srdci a že sa snažili, aby mali nástroj naozaj na úrovni, ved’ si pozvali naslovovzatého majstra-organára Jána Hummela, pôvodom z Norimbergu, ktorý bol od roku 1608 meštanom v Krakove a pred príchodom do Levoče odviedol kvalitnú prácu pri výstavbe organa v Olkuši (Olkusz, Malopol’sko). Pol’sko-spišské hudobné vztahy sú v tomto prípade dokumentované napokon aj pol’ským organárom, ktorý organ v Levoči dokončil v roku 1632 - bol ním Juraj Nitrovský (Georg Nitroffsky, Jerzy Nitrowsky).

Skutočnost', že levočský organ sa po dokončení stal jedným z najreprezentačnejších hudobnokultúrnych artefaktov vtedajšej doby na Spiši, potvrdzuje dobová tlač Dávida Frölicha (David Fröhlich) Medulla geographiae practicae (1639). Nájdeme v nej prvé hodnotenie spišských miest a mestečiek zaujímavé aj pre muzikológiu. Spišské mestá sú v nej začlenené do hornouhorského kontextu podla svojho hospodárskeho a kultúrneho významu. Ako prvé najvýznamnejšie mesto predstavuje Frölich Košice - Cassovia (metropolis est Superioris Hung[ariae]), ako druhé Levoču - Leutschovia (secunda libera Civitas, metropolis Sepusij), pričom zdôrazňuje, že je to druhé najvýznamnejšie z piatich slobodných královských miest; nasledujú šarišské mestá Bardejov - Bartpha, Prešov - Epperiessinum a Sabinov - Cibinium, Zeben a spišské mesto Kežmarok - Caesaropolis, Kaysrmarckt. Za nimi uvádza pät najdôležitejších miest spomedzi 13. miest zálohovaných Pol’sku: Spišská Nová Ves - Neocomium, sive Iglo, Newdorf; Spišské Podhradie - Varallium, Kirchdrauff; Spišský Štvrtok - Mons Georgii, Lubica - Leibicium a Spišská Belá - Bela. Z mestských sídel severného Spiša opisuje Dávid Frölich Starú Lubovňu - Lublovia, Ružbachy - Rauschenbach a Podolínec - Pudolinum; z Provincie 11 spišských miest uvádza Hrabušice - Villa Compositi, Kabsdorff a Kláštorisko-Letanovce - Mons Speculationis, Lapis Refugii. Medzi banícke mestá južného Spiša Frölich zaraduje Nálepkovo - Wagen[d]rüssel, Švedlár - Schvedler, Gelnicu - Gölniz, Smolník - Schmölniz, Medzev - Mezenseiffen, Štós - Stos a Mníšek nad Hnilcom - Einsidel, pričom detailnejšie sa venuje Smolníku. Na záver pridáva aj južnejšie mestá Dobšinú - Topschini, Štítnik - Czetnik a Rožňavu - Rosnavia. Z týchto miest je pre hudobnohistorický výskum Spiša - ale aj Slovenska (resp. Uhorska) - dôležitý opis Levoče a Spišskej Novej Vsi; v súvislosti s Levočou Frölich vyzdvihuje organ v Kostole sv. Jakuba a pri opise Spišskej Novej Vsi odporúča mesto do pozornosti čitatelov okrem iného preto, lebo malo v 17. storočí už spomínanú hudobnú spoločnost' Collegium Musicum. ${ }^{75}$

${ }_{74}$ BAL, Jeromos - FÖRSTER, Jenő - KAUFFMANN, Aurél (trans. a eds.): Hain Gáspár Löcsei Krónikája. Löcse : Reiss Józs. T. Könyvnyomó Intézete, 1910 - 1913, s. 186. GERGELYI, Otmar - WURM, Karol: Osudy chýrneho levočského organa. In: Hudobný archív 4. Martin : Matica slovenská 1981, s. 60, 61 .

75 FRÖHLICH, Ref. 57, s. 348-355. 
Informácie Dávida Frölicha sú podstatné z viacerých stránok; jednak potvrdil, že výstavba organa $\mathrm{v}$ Levoči bola naozaj v spišských parametroch významnou udalostou, ved' organ hodnotil prakticky len niekol'ko rokov po jeho dokončení. V prípade Spišskej Novej Vsi zas ide o jedinú a vel’mi cennú priamu informáciu o hudobnej spoločnosti Collegium Musicum nielen na Spiši, ale v celom severnom Uhorsku. ${ }^{76}$ Dôležitá je aj skutočnost', že Frölich ponúka prvú topografickú siet spišských miest v ich začlenení do nadregionálnych mestských štruktúr - spomína Pentapolitanu (Pätmestie: Košice, Levoča, Bardejov, Prešov, Sabinov), čiže Zväz piatich slobodných královských miest, ktoré deklarovali spoluprácu vo sfére evanjelickej cirkvi už v roku 1567. Pripomína nám to nevyhnutnost’ začlenit do výskumu nadregionálnych hudobných spišských kontaktov aj Košice. Viaceré levočské osobnosti napríklad pochádzali, resp. prichádzali do Levoče z Košíc; spomínali sme už, že aj organista Samuel Marckfelner bol pôvodom Košičan. Významný evanjelický farár Peter Zabler (ca 1578 - 1645), ktorý pochádzal z Nemecka (Hain, Meissen) a ktorý bol na post levočského farára povolaný z Košíc, pôsobil od roku 1602 v Levoči ako evanjelický farár dlhých 43 rokov. Práve Peter Zabler sa mimoriadne starostlivo venoval rozvoju evanjelického kantorátu a hudobnej kultúry mesta; on organizoval aj výstavbu organa vo farskom kostole. ${ }^{77}$

Pri hudobnotopografickom výskume Spiša je dôležité sledovat' hudobné kontakty, ktoré poskytujú práve zväzy miest a súmestia, čiže geograficky viac či menej susediace konglomerácie miest - napríklad Popradské pätmestie: Poprad, Spišská Sobota, Velká, Matejovce, Stráže pod Tatrami (dnes mestské časti Popradu). V celom regióne mali bezpochyby najlepšie podmienky rozvoja Civitas Regia - slobodné královské mestá Levoča a Kežmarok. Tie boli z mestských zväzov vyčlenené, dokonca boli vyčlenené aj zo stredovekej Provincie 24 spišských miest. Tento zväz miest bol v roku 1412 zálohovaním trinástich spišských miest a Lubovniansko-podolíneckého panstva rozdelený na dve časti: mestá zálohované Pol’sku (Provincia 13 spišských miest) a mestá nezálohované Pol'sku (Provincia 11 spišských miest). Osobitnú skupinu ešte tvorili mestá Gelnického banského okruhu s centrami v Gelnici a Smolníku. Zálohovanie spišských miest Pol'sku sa skončilo v roku 1772 počas delenia Pol'ska medzi Prusko, Rusko a Rakúsko (1772) a de facto sa tieto spišské mestá navrátili do Uhorska v roku 1778 konštituovaním Provincie 16 spišských miest; do tejto provincie sa okrem trinástich zálohovaných miest začlenila aj Stará Lubovňa, Podolínec a Hniezdne. Oficiálne názvy sídel $\mathrm{v}$ Provincii 16 spišských miest sa zachovali v levočskom archíve $\mathrm{v}$ dokumente $\mathrm{z}$ roku 1776 v zozname miest, v ktorom sú uvedené názvy v latinčine, mad’arčine, nemčine a slovenčine (Obr. 2).

V rámci Provincie 24 spišských miest existovalo od stredoveku Bratstvo 24 královských farárov, ktoré fungovalo až do roku 1674 a v časoch reformácie predstavovalo zjednocujúci činitel’ pri rozvoji evanjelických a. v. cirkví v spišských mestách. Vieme, že zasadania Bratstva 24 královských farárov sa uskutočňovali aj viackrát do roka v jednom z miest Spiša. Chronologický prehlad a opis týchto zasadaní v rokoch 1519

76 PETÖCZOVÁ, Ref. 43, kapitola „Fraternitas Litteratorum v Spišskej Novej Vsi alebo po stopách hudobnej spoločnosti Collegium Musicum na Spiši“, s. 97-150.

77 CHALUPECKÝ, Ivan: Významné evanjelické osobnosti Levoče. Peter Zabler; Štefan Xylander; Christian Pfanschmiedt a Ján Ludovít Topertzer. In: Pohlady do minulosti. Zborník prednášok $z$ histórie II. Ed. Mária Novotná. Levoča : SNM - Spišské múzeum v Levoči, 2002, s. 107-109. 
- 1705 vypracoval koncom 19. storočia významný historik Spiša József Hradszky. Problematiku rozčlenil podla osobností jednotlivých seniorov; v závere sa však nachádza aj zoznam lokalít, v ktorých evanjelickí seniori pôsobili. Lokality sú rozdelené podla cirkevných zborov v mestách Provincie 13 spišských miest a mestách Provincie 11 spišských miest, osobitne sú uvedené ešte štyri lokality: Levoča, Vel'ká Lomnica, Huncovce a Švábovce. Ak sa pozrieme napríklad na evanjelický cirkevný zbor v Poprade, nájdeme tu v rokoch 1624 - 1632 na poste seniora farára Benedikta Šimráka, otca Jána Šimráka st. ${ }^{78}$ (Obr. 3). Pri opise zasadaní sú neraz uvedené aj zmienky o hudbe a speve, resp. iné zaujímavé informácie; napríklad 17. novembra 1667, ked’ sa evanjelickí farári stretli v Odoríne, mal slávnostnú reč farár Hrabovský zo Šváboviec v slovenčine. ${ }^{79}$

Najpodrobnejšiu siet’ spišských miest z hladiska kompaktných informácií o evanjelických kantorátoch a kantoroch poskytuje rukopisne zachovaná kniha GYMNASIOLOGIA EVANGELICO-HUNGARICA, sive HISTORIA SCHOLARUM et earundem RECTORUM CELEBRIORUM. Jadro knihy vytvoril rektor prešovskej evanjelickej latinskej školy Ján Rezik (zom. 1710), po ňom ho medzi rokmi 1724 - 1728 dokončil jeho nasledovník Samuel Matthaeides a doplnili d’alší spoluautori ${ }^{80}$ Kniha vyšla tlačou až v 20. storočí v preklade do slovenčiny s názvom Gymnaziológia a poskytuje prehlad evanjelických škôl, ich rektorov a učitelov, resp. kantorov v celom Uhorsku od počiatku reformácie. Jednotlivé lokality sú zoradené podla vel'kosti a významu miest do štyroch skupín; v každej z nich nájdeme aj spišské mestá: 1) školy v královských a banských mestách - Levoča (Leutschau, Lőcse) a Kežmarok (Kesmark, Késmárk); 2) školy malomestské - Spišská Belá (Bela, Szepesbéla), Spišská Sobota (Georgenberg, Mons Sancti Georgii, Szombathely), Gelnica (Gelniczium, Göllnitz), Spišská Nová Ves (Neocomium, Zipser Neudorf, Iglo), Lubica (Leibitz), Spišské Vlachy (Wallendorf), Švedlár (Swedler), Spišské Podhradie (Warallium, Kirchdrauf, Várallya), Tvarožná (Durelsdorf, Durand), Krompachy (Krompach); 3) artikulárne dedinské školy - Batizovce (Botzdorf, Batizfalva); 4) školy v sídlach magnátov a šlachticov - Spišský Hrhov (Gorg, Görgő), Markušovce (Marksdorf, Márkusfalva) a Strážky (Nehre).

Tento prehlad poskytuje cenné kompaktné poznatky podstatné pre výskum hudobnotopografickej siete na Spiši v ranom novoveku. Ide hlavne o informácie týkajúce sa hudobného vzdelávania na spišských latinských školách prostredníctvom kantorov a učitel'ov pôsobiacich v evanjelických cirkevných zboroch. Okrem toho poskytuje dôležité informácie genealogického charakteru, týkajúce sa ich vzdelania, a to nielen domáceho, ale aj v zahraničí. Prostredníctvom životopisov učitelov a rektorov evanjelických škôl dokážeme identifikovat univerzity, na ktorých sa vzdelávali - zvyčajne to boli univerzity v mestách Wittenberg, Halle, Drážd’any (Dresden), Vroclav (Breslau), Kaliningrad (Königsberg), Toruň (Thorn), Gdansk (Danzig) a d', čiže predovšetkým v strednom a východnom Nemecku, Sliezsku a Pobaltí. Tam získavali aj hudobné vzdelanie a skúsenosti súvisiace s predvádzaním konkrétneho hudobného repertoáru

78 HRADSZKY, József: A XXIV Királyi Plébános Testvérülete (XXIV Regalium Plebanorum Fraternitas) és a Reformáczió a Szepességen. Miskolcz: Wesselényi Géza Könyvnyomdája, 1895, s. 300.

79 HRADSZKY, Ref. 78, s. 253.

80 REZIK - MATTHAEIDES, Ref. 56, s. 5-11. 
tamojších evanjelických kostolov. ${ }^{81}$ Napokon určité (viac zlomkovité) poznatky poskytuje Gymnaziológia aj k dedinským (artikulárnym) školám, preto nie je možné tieto informácie úplne z výskumu vynechat. Vo viacerých dedinách totiž existovali velmi kvalitné školy, ktoré boli podhubím pre výchovu budúcich spevákov a hudobníkov tamojších - i ked' rozsahom menších - kantorátov. Dvaja rektori (Daniel Ölsner, Samuel Frölich) sa spomínajú menovite napríklad aj v menšej dedinskej škole v Batizovciach (dnes okres Poprad), v lokalite, ktorá patrila v 17. storočí Máriássyovcom. V tomto prekrásnom prostredí pod vysokými Tatrami (dva kilometre na severozápad od Svitu) pôsobil v evanjelickej cirkvi v rokoch 1682 až 1688 už spomínaný farár Juraj Bucholtz st., v histórii Spiša zapísaný ako chýrny, priekopnícky bádatel' Vysokých Tatier, v dejinách hudby známy svojím uznanlivým výrokom o pestovaní viaczborovej hudby v nedalekých Matejovciach a Spišskej Sobote.

\section{Ad IV. Archívne pramene obsahujúce informácie o hudobnom živote}

Štvrtú dôležitú skupinu zachovaných prameňov potrebných k poznaniu hudobnotopografickej siete na Spiši tvoria sekundárne archívne pramene obsahujúce informácie o hudobnom živote. Môžu mat rôzny charakter; môžu obsahovat informácie o individuálnych hudobníkoch rôznych konfesií (matriky, listy, vokácie), informácie o lokálnych javoch (nákup hudobnín a hudobných nástrojov) alebo informácie nadregionálneho charakteru (o cestovaní, štúdiu, a pod.). Pre hudobnotopografický výskum sú dôležité všetky základné typy všeobecnohistorických prameňov, ktorých kategorizáciu zhrnula Eva Szórádová (2001): 1) matriky narodených, sobášených, zomretých;2) knihy novoprijatých meštanov; 3) súpisy obyvatelstva; 4) daňové knihy, hlavne daňové knihy remeselníkov; 5) živnostenské protokoly a cechové knihy; 6) účtovné knihy; 7) magistrátne a spisové protokoly. ${ }^{82} \mathrm{~V}$ každom z týchto archívnych dokumentov môžeme nájst' určitý typ miestopisných údajov. $\mathrm{V}$ matrikách sú to údaje o mieste narodenia a úmrtia hudobníkov, v knihách novoprijatých meštanov sú to údaje o mieste ich bydliska a pôsobenia (aktuálneho, resp. predchádzajúceho), v súpisoch obyvatelstva dokážeme sledovat stahovanie hudobníkov v rámci jednej lokality, v daňových knihách nájdeme tiež údaje $\mathrm{k}$ miestu bydliska.

Osobitne dôležitú skupinu archívnych prameňov predstavuje korešpondencia, predovšetkým listy samotných hudobníkov a listy týkajúce sa hudby, resp. hudobného života. Dôležitá je tiež korešpondencia učitelov, rektorov, farárov, niekedy i členov mestskej rady, lebo každý z nich sa mohol určitým spôsobom podielat na rozvoji mestského kantorátu. Takýchto listov sa z obdobia raného novoveku na Spiši nezachovalo vela, preto tie, ktoré máme $\mathrm{k}$ dispozícii, sú cenným zdrojom poznatkov. Jeden z takýchto vzácnych listov sa nachádza v levočskom archíve - napísal ho v roku 1614 nemecký kantor Valentin(us) Ritter z mesta Großenhain (Hain, Meissen, Sasko) richtárovi mesta Levoča. Ritter v ňom spomína farára Petra Zablera, ktorého sestru mal za manželku.

81 KALINAYOVÁ, Jana: Hudobné aktivity spišských evanjelikov v Nemecku. In: Musicologica Slovaca et Europaea 19, 1994, s. 53-62.

82 SZÓRÁDOVÁ, Eva: Všeobecnohistorické pramene v hudobnej historiografii. In: Ad honorem Richard Rybarič. Ed. Janka Petőczová. Bratislava : Ústav hudobnej vedy SAV, 2011, s. 134-141. 
Vieme, že dlhoročný superintendent levočskej evanjelickej cirkvi Peter Zabler naozaj pochádzal z Nemecka (Meissen) a počas celého obdobia pôsobenia na Spiši v prvej polovici 17. storočia udržiaval kontakty s rodným nemeckým prostredím. Zaujímavý je aj samotný obsah listu. Meissenský kantor Valentin Ritter v liste ponúka Levočanom odpis pašií od Antonia Scandella (1517 - 1580), ktoré sa spievajú u nich v škole. Píše tiež, že pašie nevyšli tlačou, nie je možné ich kúpit, ale že on má jeden exemplár, z ktorého ich môže Levočanom opísat' Z listu tiež vyplýva, že Levočania boli v Haine na návšteve, počuli a spievali Scandellove pašie v kostole a prejavili o ne záujem. Počas tých niekolkých dní, ktoré tam strávili, však nebolo možné pre nich toto rozsiahle dielo opísat. ${ }^{33}$ Samotný list poukazuje nielen na hudobný repertoár a možnosti jeho transmisie na Spiš, ale referuje aj o migrácii Spišiakov do jednej z konkrétnych nemeckých oblastí Saska, do mesta Meissen, ktoré je málo známe v kontexte spišsko-nemeckých hudobných kontaktov; skôr ho poznáme prostredníctvom uznávaného meissenského porcelánu - mimochodom aj porcelánu s cibulovým vzorom, ktorý sa neskôr začal podla meissenského vzoru vyrábat i v Čechách.

Závažnú skupinu prameňov pri hudobnotopografickom výskume spišských lokalít predstavujú rukopisné mestské knihy, dôležité archívne dokumenty nachádzajúce sa vo fondoch magistrátov spišských miest; ich význam stúpa hlavne pri výskume miest, $\mathrm{v}$ ktorých sa nezachovali primárne hudobné pramene. Jednou z takých lokalít je aj mesto Spišské Vlachy (Wallendorf, dnes obec v okrese Spišská Nová Ves), ktoré v ranom novoveku patrilo spolu so Spišským Podhradím a Spišskou Novou Vsou k mestám stredného Spiša z Provincie 13 spišských miest zálohovaných Polsku. Prosperitu zabezpečoval Spišským Vlachom rozvoj remesiel a obchodu, ktorý podporovala výhodná poloha na dôležitej obchodnej ceste spájajúcej Krakov a Šariš so spišskými banskými mestami, pokračujúca na juh smerom na Gelnicu a Jasov (tzv. Uhorská cesta). Z magistrátnych dokumentov Spišských Vlachov majú dôležitú výpovednú hodnotu pre hudobnú historiografiu dve mestské knihy nazvané Urbarium, prvá z rokov 1616 - 1677 a druhá z rokov 1678 - 1752, v ktorých sa pravidelne vyskytujú informácie o hudbe a hudobníkoch v 17. storočí, resp. o pedagógoch mestskej latinskej školy a inštrumentálnych hudobníkoch platených mestom. ${ }^{84}$ Doplnit’ sa dajú informáciami z d’alších mestských kníh zmlúv a testamentov z rokov 1596 - 1767, z ktorých je možné rekonštruovat majetkové pomery meštanov. ${ }^{85}$ Najstaršia informácia o existencii organa v Spišských Vlachoch pochádza z roku 1622, ked' mesto zaplatilo za renováciu (resp. prestavbu) organa 41 zlatých a 72 denárov - Auf die Orgell aufgangen Müntz. ${ }^{86}$ Práce prebiehali dlhší čas, lebo mesto platilo na etapy. Podla účtovných dokumentov v meste pôsobili nasledovní organisti: David Hartman v rokoch 1636 - 1637; Jacob

83 Spišský archív v Levoči, Magistrát mesta Levoča, Listina a listy, sign. V. 78/14. Fotokópia a transkripcia listu: PETŐCZOVÁ, Janka. Zipser-deutsche musikalische Wechselbeziehungen im 17. Jahrhundert. In: Barockmusik als europäischer Brückenschlag : Festschrift für Klaus-Peter Koch. Ed. Claudia Behn. Beeskow : Ortus Musikverlag, 2019, s. 50-54.

84 Štátny archív v Košiciach (ŠA-K), Archív Spišská Nová Ves (A-SNV), Magistrát mesta Spišské Vlachy (MM-SpV), Urbarium - Kniha mesta (prvá), 1616 - 1677 sign. 2[a]; Urbarium - Kniha mesta (druhá), 1678 - 1752, sign. 2[b].

85 ŠA-K, A-SNV, MM-SpV, Knihy zmlúv a testamentov, 1596 - 1634, $1634-1659,1665$ - 1703, 1704 - 1767, sign. 11[a], 11[b], 12, 13.

86 ŠA-K, A-SNV, MM-SpV, Ref. 85, sign. 2[a], s. 44. 
Weiß (Weÿß) v rokoch 1637 - 1638; Andreas Tinctoris v rokoch 1639 - 1640 (resp. do 1646); Samuel Marckfelner v rokoch 1647 - 1648; Israel Müller v rokoch 1649 - ca 1667 a Gallus Peltz (Peltzio) v rokoch $1679-1700 .^{87}$ Aj tieto dokumenty potvrdzujú informácie z levočských archiválií, že Samuel Marckfelner naozaj pôsobil pred príchodom do Levoče v Spišských Vlachoch. Organ, na ktorom hral, sa však nezachoval. O rozkvet evanjelického kantorátu v Spišských Vlachoch sa až do protireformácie v 17. storočí starali známe osobnosti; v rokoch 1646 - 1667 to bol evanjelický farár magister Andrej (Andreas) Günther a v rokoch 1668 - 1674 Daniel Klesch (1619 - 1697), absolvent niekolkých zahraničných univerzít a jeden z najvýznamnejších evanjelických farárov, nositel' titulu poeta laureatus (Keyserlichen Poëten), ktorý mal aj kvalitné hudobné vzdelanie. ${ }^{88}$ Zachovali sa jeho piesne, publikované neskôr, počas jeho exilu, ako samostatné príležitostné tlače, resp. v rámci spevníkov. ${ }^{89}$

Osobitnú pozornost je potrebné venovat aj vonkajším parametrom archívnych prameňov (väzba, obal, rozmer, použitý materiál), pretože mnohé magistrátne a spisové dokumenty boli po ukončení záznamov zväzované do knižnej väzby, na ktorú sa používali staršie archy papiera, nevynímajúc notový papier. Takýmto spôsobom sa neraz dostaneme $\mathrm{k}$ hudobninám, ktoré sa $\mathrm{v}$ čase vyhotovovania knižnej väzby už nepoužívali, ale pre muzikológiu - ak sú ešte čitatel’né - majú aj vo fragmentárnej podobe (orezané, lepené vo väzbe) mimoriadny význam. $\mathrm{V}$ tomto prípade je určitým identifikátorom používania hudobniny in situ a argumentom ex silentio samotná existencia mestskej knihy. Jeden z takýchto najnovších zaujímavých nálezov sa podaril v Spišskej Novej Vsi. Vo väzbe účtovnej knihy vedenej v rokoch 1514 - 1524 (sign. K/I 28) sa zachovali vo vnútornej strane prednej a zadnej dosky obalu rukopisné notované papierové fólie. Ide o fragmenty troch viachlasných skladieb notovaných bielou menzurálnou notáciou oválneho tvaru s kolorovaním. Skladby reprezentujú renesančnú polyfonickú duchovnú hudbu, ktorá sa s najväčšou pravdepodobnostou predvádzala v tamojšom farskom kostole v 16. storočí (hymnus na sv. Katarínu, fragment viachlasnej omše, responzórium Gaudet exercitus Angelorum). Tieto unikátne hudobné zlomky môžeme považovat za priame svedectvo o renesančnom hudobnom repertoári spievanom novoveským literátskym bratstvom vo farskom Kostole Nanebovzatia Panny Márie ${ }^{90}$ (Obr. 4).

Archívne pramene obsahujúce informácie nadregionálneho charakteru si zvyčajne vyžadujú spracovanie väčšieho objemu dát. Rozsiahlejšie informačné databázy $\mathrm{k}$ hudobnému životu sa však zachovali až od 18. storočia. V slovenskej hudobnej historiografii vytvorila takúto rozsiahlu databázu Darina Múdra, ktorá spracovala údaje o hudobníkoch a organoch v katolíckych kostoloch na základe kanonických vizitácií z rokov 1751 - 1833. Región Spiša tu reprezentujú údaje o hudbe z 362 vizitácií, na základe ktorých autorka predkladá 181 lokalít s doloženou prítomnostou hudby a v ich

87 ŠA-K, A-SNV, MM-SpV, Ref. 85; menom a priezviskom sa organisti uvádzajú až od roku 1636.

${ }_{88}$ PETRÍK, Borislav - RYBÁR, Peter (zost.): Evanjelická encyklopédia Slovenska. Bratislava : BoPo, GBÚ ECAV, 2001, s. 344.

89 Pät melódií piesní so sprievodom generálneho basu Festorum anniversariorum et primariorum nativitati, resurrectionis, ascens. Christi (Jena 1677), pohrebná pieseň pre štyri hlasy Letztes Testament und Froeliches Sterb-Lied (1681). KALINAYOVÁ, Ref. 81, s. 57-61.

90

PETÖCZOVÁ, Ref. 43, s. 132-134. 
rámci 316 mien hudobníkov. ${ }^{91} \mathrm{Na}$ základe týchto údajov vieme rozpoznat aj hudobnotopografickú siet', ktorú určujú hudobné javy v katolíckom hudobnokultúrnom prostredí, a to prostredníctvom dobových informácií o vzdelaní a kvalitách hudobníkov, o existencii a vel'kosti organov (v niektorých lokalitách aj iných hudobných nástrojov) a o vývine pestovania viachlasnej hudby (musica figuralis) v rovnakých lokalitách. Ked'že ide o obdobie rekatolizácie, v tejto hudobnotopografickej sieti - prirodzene - vyniká rímskokatolícke cirkevné centrum Spišská Kapitula. Ostatné parametre vývinu hudobnej kultúry spišských miest ostávajú relatívne také, ako ich poznáme z predchádzajúceho storočia: za „srdce kultúry Spiša“ označuje Darina Múdra Levoču, na východ a na juh od Levoče to boli okrem Spišskej Kapituly aj mestá Spišské Podhradie, Spišské Vlachy, Spišská Nová Ves, na západ od Levoče to boli mestá Poprad, Spišská Sobota, Vrbov, Lubica, Kežmarok, Spišská Belá a Slovenská Ves; na území horného Spiša (lokalizovaného na sever od Slovenskej Vsi) to boli mestá Stará Lubovňa, Spišská Stará Ves a Podolínec, na území dolného Spiša to boli mestá Gelnica, Švedlár, Smolník a Smolnícka Huta. Všetky lokality spišského hudobnokultúrneho okruhu uvádza Darina Múdra v dvoch zoznamoch: lokality Spišskej stolice s doloženou prítomnostou organov: 129 lokalít (dnešné obce a mestá Spiša), a lokality Spišskej stolice s doloženou prítomnostou iných hudobných nástrojov: 24 lokalít (zv. I, prílohy 9-11). Osobitne je uvedený zoznam hudobníkov Spišskej stolice (zv. I, príloha 12), zoznam kanonických vizitácií s rozpisom hudobných javov uvedených vo vizitáciách v Spišskom biskupstve od roku 1751, zoznam iných kanonických vizitácií (rehole, farské, štátne a zahraničné archívy) a d’alších dokumentov (dobové inventáre hudobnín). ${ }^{92}$

\section{Ad V. Historické mapy}

Piatu skupinu zachovaných prameňov dôležitých pre hudobnú topografiu tvoria mapy, ktoré poskytujú pohlad na geografický reliéf regiónu a umožňujú z nadhladu sledovat’ odlišnosti v územnom a správnom vývoji miest i vo vývoji ich administratívnej a cirkevnej správy. Z mapových vyobrazení Spiša má muzikológ k dispozícii viacero dokumentov. Najstaršiu kolorovanú mapu Spiša Ichnographische delineation des ganzen Zipser Comitates v mierke 1: 116000 vyhotovil na pergamene Jakub Kray v roku 1715. Po jeho smrti vyšla tlačou mierne modifikovaná a o polovicu menšia v diele Mateja Bela Hungariae antiquae et novae prodromus (Norimberg 1723). Z 18. storočia sa zachovali čiastkové nákresy Spiša od Juraja Buchholtza ml. (1717) a Samuela Mikovíniho (1740), tvoriace podklady pre azda najznámejšiu mapu Spiša, ktorá vyšla v diele Jána Mateja Korabinského Novissima Regni Hungariae Potamographica et telluris Productorum (1791) ako súčast’ mapy Uhorského královstva); následne vyšla tlačou v roku 1794 v jeho príručnom atlase Atlas Regni Hungariae portatilis: ein geographisches Noth- und

${ }^{91}$ MÚDRA, Ref. 16, s. 69. Takáto hustá siet’ lokalít sa už približuje ku dnešnému číslu evidovaných obcí a miest na Spiši na Slovensku, ktorých je 185 (štatistické údaje z r. 2015). Dostupné na internete: https://sk.wikipedia.org/wiki/Zoznam_obc\%C3\%AD_Spišskej_župy.

92 MÚDRA, Ref. 16, zv. I, s. 231-235; zv. I, prílohy 9-11, s. 367-372; zv. I, príloha 12, s. 372-377; zv. II, s. 676-767; zv. II, s. 879-946. 
Hülfsbüchlein (1804). ${ }^{93}$ Táto mapa zachytáva nielen prírodno-geografické pomery Spiša a polohu sídel, ale aj základnú cestnú siet a poštové stanice. Názvy väčšiny sídel sú nemecké, ale nachádzajú sa tu aj mad’arské a slovenské varianty. V spodnej časti mapy je umiestnený erb Spišskej stolice, ktorého súčastou je aj erb Thurzovcov (lev sprevádzaný dvoma ružami). Mapa je dôležitá $\mathrm{v}$ nadregionálnom kontexte; $\mathrm{v}$ rámci celouhorského priestoru vyniká husté osídlenie Spiša. Dôležité je aj vizuálne znázornenie velkosti miest a ich statusu kartografickými značkami: dve slobodné královské mestá Kežmarok a Levoča majú symbol plného podstavca, na ktorom sa nachádza symbol cirkevnej moci (dve kostolné veže), sídla Provincie 16 spišských miest majú podstavec s rímskym číslom XVI, menšie mestá nemajú podstavec pod kostolnou vežou a sú odstupňované až po dedinky, znázornené len bodovo. Historická mapa lokalizuje aj hrady a pevnosti: Spišský hrad (Zipserhauß), kaštiel v Spišskom Štiavniku (Arx Scavnik), Hrad Nedeca (Arx Dunavetz), Lubovniansky hrad (Arx Lublo) a štyri poštové stanice: Levoča, Korytné, Lučivná (Lutsivna) a Hozelec (Hozeletz). Z rukopisných máp spomeňme ešte dve zaujímavé mapy Spiša, ktoré sa nachádzajú v Spišskom archíve v Levoči - kolorovaná Administratívna mapa Spišskej župy (ca 1780) Andreja Marka a Mapa Spišskej župy z roku 1794, ktorá je zaujímavá kolorovaným zvýraznením červenou farbou miest zálohovaných Polsku (Provincia 13 spišských miest) ${ }^{94}$ (Obr. 5).

Mapy Spiša sú konečným bodom, v ktorom je možné sumarizovat hudobnotopografickú siet $z$ hladiska administratívno-správneho i viacdimenzionálneho cirkevného a kultúrneho vývinu spišských miest. Mapy ulahčujú možnost’ spojit jednotlivé informácie o hudobníkoch, hudobných inštitúciách a hudobnom živote, a zároveň názorne dokumentujú cesty šírenia hudby a možnosti migrácie hudobníkov na regionálnej i lokálnej úrovni. Ideálne je spojit techniku čítania máp a celkovú znalost geografického terénu, čo pomáha objasňovat dynamiku celého procesu. Základom je poznat historické názvy lokalít a štruktúru súmestí (zväzov miest) v chronologických vývinových kontextoch. Mapy pripomínajú, že hudobné dejiny Spiša sú polyvalentné a premenlivé - v určitých etapách ich reprezentovali predovšetkým evanjelické mestské kantoráty, $\mathrm{v}$ iných etapách bol prosperujúcejší hudobný život v katolíckych kostoloch. Pri záverečnom vyhodnocovaní nemôžeme obíst' ani svetské sídla, hlavne sídla šlachty a mestskej aristokracie.

Napokon, mapy poskytujú východisko k bádaniam zameraným na dejiny hudby v jednotlivých mestách (individuálnych lokalitách), ktoré majú svoju vnútornú hudobnotopografickú siet. Čím je mesto väčšie a jeho vnútorná siet širšia, tým komplikovanejší je výskum vnútorných hudobných kontextov. Spišské mestá nepatrili

93 Dostupné na internete: https://books.google.sk/books?id=DxiE_38FPc8C\&printsec=frontcover\&dq=Korabinsky+Atlas + regni + hungariae $\&$ hl $=$ sk\&sa $=X \& v e d=2 a h U K E w j l x I L 9 s N-$ 7rAhXLqaQKHQQ4BYoQ6AEwAHoECAMQAg\#v=onepage\&q=Korabinsky\%20Atlas\%20 regni\%20hungariae\&f=false. Mapa Pavla Kraya sa zachovala v Archíve v Poprade (Poprad-Spišská Sobota). Historia Scepusii : Vol. II. Dejiny Spiša od roku 1526 do roku 1918. Eds. Martin Homza, Stanisław A. Sroka. Bratislava : Katedra slovenských dejín FiF UK; Kraków : Instytut Historii Uniwersytetu Jagiellońskiego, 2016, s. 327-330. Terra Scepusiensis. Stav bádania o dejinách Spiša. Stan badań nad dziejami Spiszu. Eds. Ryszard Gładkiewicz, Martin Homza, Michał Pułaski, Michal Slivka. Levoča; Wrocław : Kláštorisko, 2003, s. 252.

94 Spišský archív v Levoči. Spišská župa, kongregačné písomnosti, inv. č. 628, šk. 299, č. spisu 419/1794. 
v stredoeurópskom kontexte k vel'kým sídlam. Dokonca z hladiska stredoeurópskej demografie to boli mestá relatívne malé; v polovici 16. storočia mal Poprad 595 obyvatel’ov, Spišská Sobota 394, Vel'ká 406, Stráže 300 a Matejovce 250. Na konci 17. storočia mal Poprad - najväčšie spomedzi trinástich zálohovaných miest Pol’sku 1003 obyvatel'ov, Spišská Sobota mala 828 obyvatel'ov, Vel'ká 626 obyvatel'ov, Stráže 505 obyvatel'ov a Matejovce 265 obyvatelov. V 18. storočí sa ekonomicky i demograficky rozvinula Spišská Nová Ves, ktorá mala v roku 1758 už 2772 obyvatelov, k čomu prispel rozvoj baníctva. Najväčšími mestami Spiša však stabilne ostávali Kežmarok a Levoča vdaka rozvoju remesiel a obchodu. Levoča mala v čase najväčšieho rozkvetu v 17. storočí maximálne 5000 obyvatelov. ${ }^{95}$ Avšak na prelome 17. a 18. storočia tu žilo len okolo 3500 obyvatel’ov. O sto rokov neskôr, v čase konsolidácie konfesionálnej situácie na Spiši, bolo v Levoči podla kanonickej vizitácie z roku 1804 evidovaných 4434 obyvatelov (Nemcov a Slovákov), pričom 2534 bolo katolíkov a 1900 nekatolíkov. V porovnaní so stredoeurópskymi mestami mal podobnú vel'kost’ napríklad sliezsky Breh (Brzeg, PL). $\mathrm{V}$ ranom novoveku však len $\mathrm{v}$ Pol'sku existovalo sedem miest s počtom obyvatelov viac než desattisíc a všetky patrili k významným centrám pestovania hudobnej kultúry Kraków, Lwów, Poznań, Warszawa, Gdańsk, Elbląg, Toruń. ${ }^{96}$

Poznanie hudobnotopografických súvislostí prostredníctvom máp v rámci jednotlivých miest umožňuje rozšírit nazeranie na hudobný život cez prizmu vnútorných vztahov medzi ich jednotlivými hudobnými inštitúciami (kostoly, kaplnky, školy). Napríklad v Levoči bol v polovici 17. storočia hlavným centrom umeleckej hudby farský Kostol sv. Jakuba, o sto rokov neskôr sa tu rozvíjal hudobný život už v štyroch kostoloch, ktoré navonok reprezentujú ich historické organy: v jednom novopostavenom drevenom evanjelickom kostole za hradbami mesta a v troch rímskokatolíckych kostoloch: vo farskom kostole (dnes Bazilika minor sv. Jakuba), v Kostole Svätého Ducha a v Kostole Panny Márie Královnej anjelov a sv. Ladislava, t. j. v bývalom minoritskom, resp. starom jezuitskom gymnaziálnom kostole (nazývanom aj Čierny kostol). Kedže v 18. storočí sa rozvinul v Levoči aj hudobný život v bohatých meštianskych a šlachtických rodinách (Thurzovci), dokážeme na mapu mesta zakreslit’ aj konkrétne meštianske domy, v ktorých sa dokázatelne pestovala hudba (napríklad Lumnitzerovcov, Güntherovcov, Okolicsányiovcov). Napokon nemôžeme zabudnút' ani na sídla šlachty (Thökölyovci na Kežmarskom hrade, Máriássyovci v Markušovciach), resp. bohatších rodov, napríklad majitelov kaštiel’a v Strážkach (dnes súčast’ mesta Spišská Belá).

Kaštiel' v Strážkach je jednou z menej prebádaných lokalít Spiša napriek skutočnosti, že už najstaršia hudobná história sídla je spojená s pestovaním renesančnej polyfonickej hudby počas spravovania kaštiela prvým vlastníckym rodom Horvath-Stansithovcov. Pod ich egidou tu existovala v rokoch 1588 - 1711 významná evanjelická škola. Z majetku zakladatela školy Gregora Horvath-Stansitha pochádzajú jedny z najstarších rukopisných hudobných prameňov zachovaných na území Slovenska, obsahujúcich vokálnu polyfonickú hudbu. Ide o vzácne hlasové zošity sign. Ms. Mus. Bártfa 15 zachované v Bardejovskej evanjelickej zbierke hudobnín (nekompletne),

95 Historia Scepusii : Vol. II., Ref. 93, s. 272-274.

96 PRZYBYSZEWSKA-JARMIŃSKA, Barbara: Historia Muzyki Polskiej tom III, BAROK, część pierwsza, 1595-1696. Ed. Stefan Sutkowski. Warszaw : Sutkowski Edition Warsaw, 2006, s. 25-26. 
ktoré obsahujú posesorský záznam o kúpe rukopisu Gregorom Horvathom-Stansithom od Martina Eckmanna z Lužice (Lusatio): „Emptae partes istae in usum Ecclesiae Neeren[sis] per generosum dominum Gregorium H[orvath] S[tansith] a Martino Ekman Lusatio fl. 1 d. 50 die 6 Aprilis secundum Vetus: Anno 1593“.97 Obsahujú polyfonickú hudbu, ktorá sa predvádzala v evanjelickom kostole v Strážkach koncom 16. storočia, a to 5- až 6-hlasné omše a magnifikaty od Orlanda di Lasso (1532 1594), Philippa de Monte (1521 - 1603), Johanna Knöfelia (1525 - 1617) a Davida Thusia (16./17. st.). ${ }^{98} \mathrm{~V}$ kaštieli v Strážkach pokračoval intenzívny rozvoj pestovania hudby aj v 18. storočí. Anna Mária (Nanette) Horvath-Stansithová (vyd. Szirmayová, 1772 - 1807), neter spišského grófa a vicežupana Imricha (Emerich) Horvath-Stansitha (1741 - 1801), bola vynikajúcou speváčkou a klaviristkou. Spev a hru na klavíri študovala vo Viedni (1785/1786). Zachoval sa jej obraz - podobizeň sediacej Anny Márie pri čembale z obdobia pred jej vydajom za Andreja (III.) Szirmayho v roku $1790 .{ }^{99}$

\section{Záver}

Vytýčenie hudobnotopografickej siete v premenlivých súradniciach je základnou metódou umožňujúcou komplexný pohlad na hudobný život regiónu Spiš. Ak by sme si položili otázku, či je niektoré z vyššie uvedených hladísk pri vytyčovaní tejto siete dôležitejšie, odpoved' nebude jednoduchá. Z hladiska poznania samotnej hudby je pravdaže dominantné hladisko zachovaných primárnych hudobných prameňov; tie poskytujú možnosti výskumu hudobných diel a hudobného repertoáru, čiže šírenia a migrácie hudby v stredoeurópskom priestore. Pre Spiš ostáva až do roku 1830 realitou, že sa tu zachovali od profesionálnych hudobníkov diela signované autorsky ako opus musicum od skladatelov pôsobiacich $\mathrm{v}$ službách cirkvi - či už to bol evanjelický kantorát alebo cirkevní hudobníci katolíckych kostolov a reholí. Komplexný pohlad na dejiny hudby v regióne si však vyžaduje koordináciu všetkých piatich hladísk. Popri primárnych sú dôležité sekundárne hudobné pramene, lebo poskytujú informácie k biografii hudobníkov (štúdium, peregrinácie, migrácia, sociálne postavenie) i k lokálnemu, konfesionálne a etnicky diferencovanému hudobnému životu (hudobné lokality, ich vel'kost',

97 MURÁNYI, Róbert Árpád: Thematisches Verzeichnis der Musiksammlung von Bartfeld (Bártfa). (= Deutsche Musik im Osten, 2). Bonn : Gudrun Schröder Verlag, 1991, s. XI, s. 47-48.

$98 \mathrm{Z}$ územia historického Uhorska sa diela Davida Thusia zachovali z Bardejova, z Levoče a z Banskej Bystrice. GREŠOVÁ, Adriana: David Thusius ex Comitatu Mansefeldico (16. - 17. storočie / 16th-17th Century): Magnificat octavi toni (= Musicalia Istropolitana 10). Bratislava : STIMUL, 2019. Dostupné na internete: https://www.academia.edu/41255531/David_Thusius_ex_Comitatu_Mansefeldico_16_17_storočie_16th_17th_Century_Magnificat_octavi_toni. V Krakove sa napríklad zachovala autorská tlač z roku 1609 EPITHALAMION Musicis numeris exornatum \& compositum cum sex vocibus. PATALAS, Aleksandra: Catalogue of Early Music Prints from the Former Preußische Staatsbibliothek in Berlin, Kept at the Jagiellonian Library in Cracow. Kraków : Musica Iagellonica, 1999, s. 359, 441.

99 SZÓRÁDOVÁ, Ref. 64, s. 31. Reprodukcia obrazu s podobizňou Anny Márie pri čembale: Slovenská hudba, roč. 24, 1998, č. 3, 1. strana obálky. JANURA, Tomáš - HAVIAROVÁ, Michaela: Vidiecke šlachtické sídla v Spišskej stolici. Bratislava : Spoločnost̉ Kolomana Sokola, 2019, s. 126. 
vnútorné členenie, význam, porovnanie v regionálnom a transregionálnom priestore). Výskum zohladňujúci všetky uvedené hladiská je nesmierne náročný na čas, ale tiež na zovšeobecňovanie; umožňuje však prekonat problém nerovnomernosti zachovaných prameňov a umožňuje presnejšie definovat jedinečné, lokálne a spoločné, regionálne prvky v dejinách hudby a hudobnej kultúry v historickej Spišskej stolici.

Štúdia je súčastou riešenia grantového projektu VEGA č. 2/0012/21 Migrácia hudobníkov a transmisia hudby v 17. - 19. storočí na Slovensku a v strednej Európe, roky riešenia: 2021 - 2024; pracovisko riešitelky: Ústav hudobnej vedy SAV.

Obrázky sú reprodukované s láskavým povolením Cirkevného zboru ECAV na Slovensku Levoča; Štátneho archívu v Prešove, Špecializovaného pracoviska Spišský archív v Levoči a Štátneho archívu v Košiciach, pracoviska Archív Spišská Nová Ves. 


\section{OBRAZOVÁ PRÍLOHA}

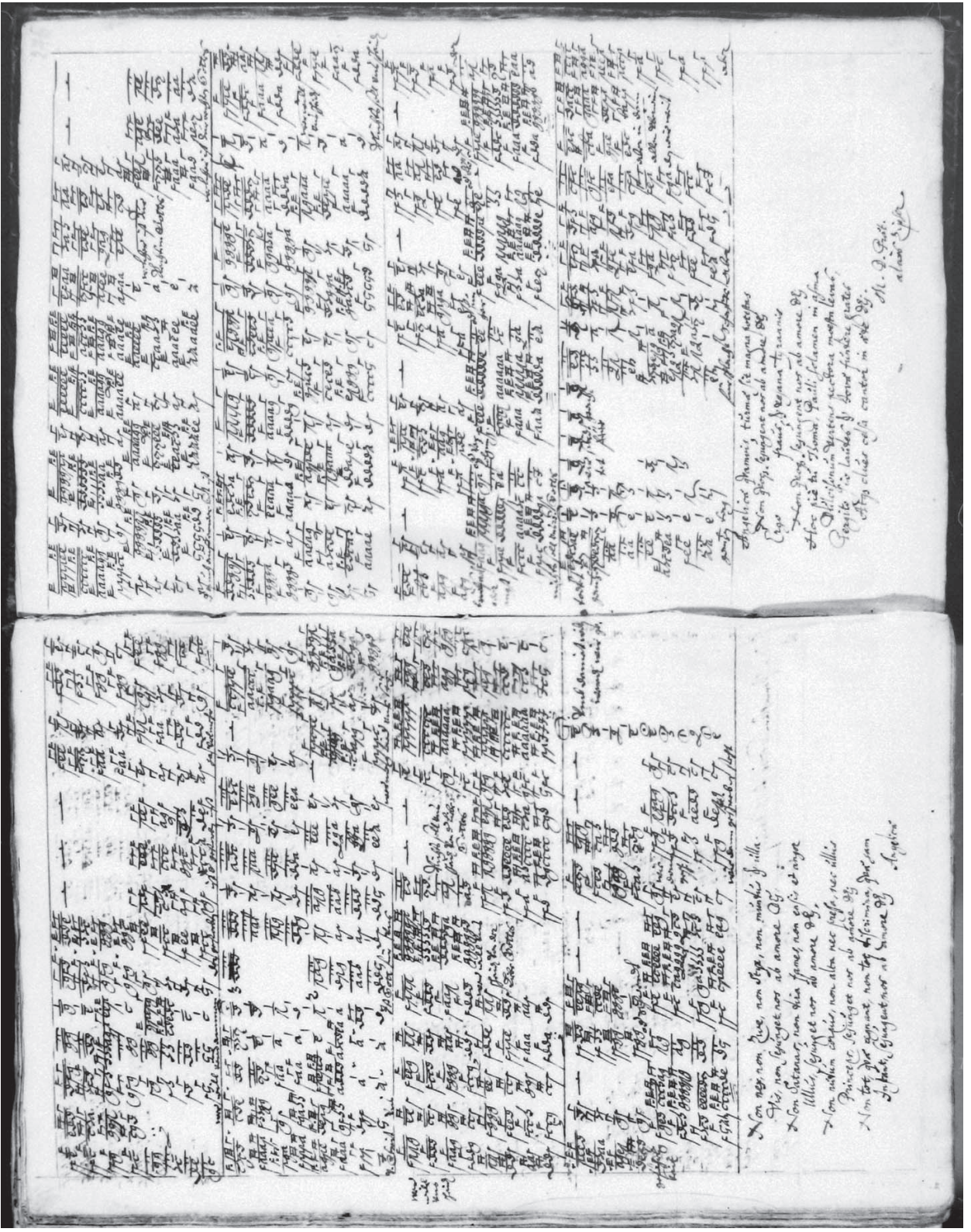

Obr. 1: M. D. Praet. | alaus Zipser. Báseň Dávida Praetoria, 1642. Tabulatúrny zborník, SK-Le MUS A 3, f. $274^{\mathrm{v}}-275^{\mathrm{r}}$

(C) Cirkevný zbor Evanjelickej cirkvi a. v. na Slovensku Levoča. Foto: Janka Petőczová 


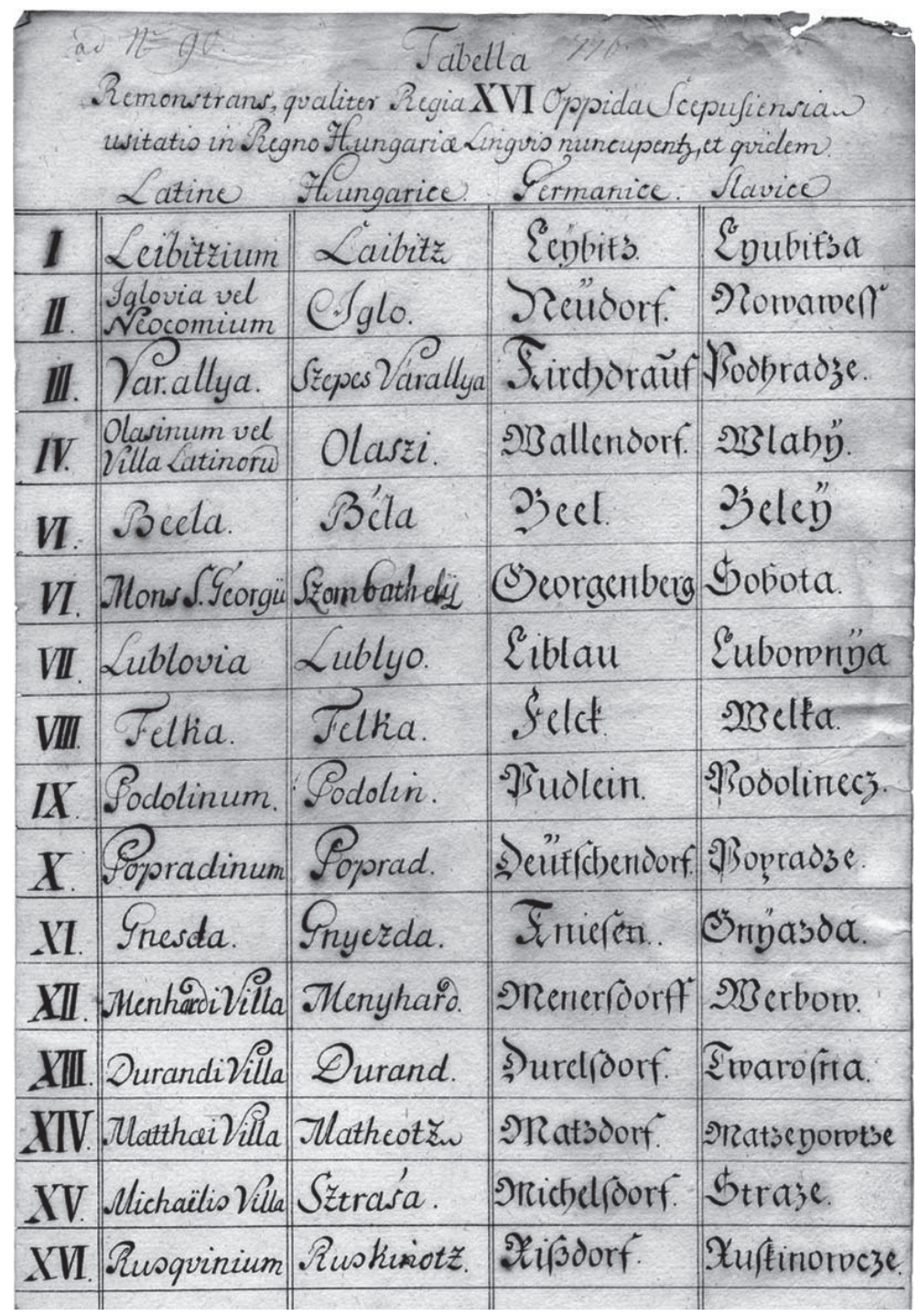

Obr. 2: Tabul'ka oficiálnych názvov Provincie 16 spišských miest, 1776.

(c) Spišský archív v Levoči. Foto: Štefan Péchy 


\section{Poprád.}

1. Topperczer Antal . 1557-ig

2. Gniesner Bálint. $1565-1584$.

3. Christophori Máté . 1584-1622.

4. Arelt Márton. . 1622-1624.

5. Schimrak Benedek . 1624-1632.

6. Sturm Dániel . . 1632-1645.

7. Weisz Tóbiás. . 1645-1674.

\section{Felka.}

1. Filker Gergely . . 1552-1575.

2. Matern (Midvischer)

János . . . 1575-1581.

6. Sylvester János . . 1608-1618.

7. Reimann Márton . 1619-1624.

3. Nikasy György · . 1581- 1600 .

8. Arelt Gergely . . 1625-1641.

4. Grensner Márton $1600-1605$.

9. Praetorius Gergely. $1541-1645$.

5. Weisz Tóbiás . 1605-1608.

10. Hertel Ezsaiás . 1645-ben.

11. Novoscius Mihály . 1646-1674.

\section{Matheócz.}

(A matheóczi és a mihályfalvi lelkészek nem tartoztak ugyan a XXIV kir. lelkész szövetkezetébe, hanem a felsö-poprádi fraternitáshoz, de teljesség kedveért ide iktatjuk okket.)

1. Suchiny Péter . . 1573-tól.

5. Pilarik Ezsaiás . . 1646-1656.

2. Botzdorfer Szervácz. $1574-1597$.

6. Klesch Kristóf . . 1656-1661.

3. Weisz Tóbiás . . 1597-1601.

7. Heutsch Fülöp . 1661-1670.

4. Hortensius József . 1601-1645.

8. Langsfeld Keresztély 1670-1674.

\section{Mihály falva.}

1. Botzdorfer Szervácz. 1566.

2. Gulden János • . 1584.

3. Eichel Izsák • . 1595.

4. Hermelius János . 1600-ig.
5. Weisz Tóbiás . . 1601-1606.

6. Fabricius Sebestyén. 1606-1623.

7. Klein Kelemen . 1623-1653.

8. Schwartz András . 1653-1674.

Obr. 3: Benedikt Šimrák, evanjelický farár v Poprade v rokoch 1624 - 1632. In: HRADSZKY, József: A XXIV Királyi Plébános Testvérülete, 1895, s. 300 


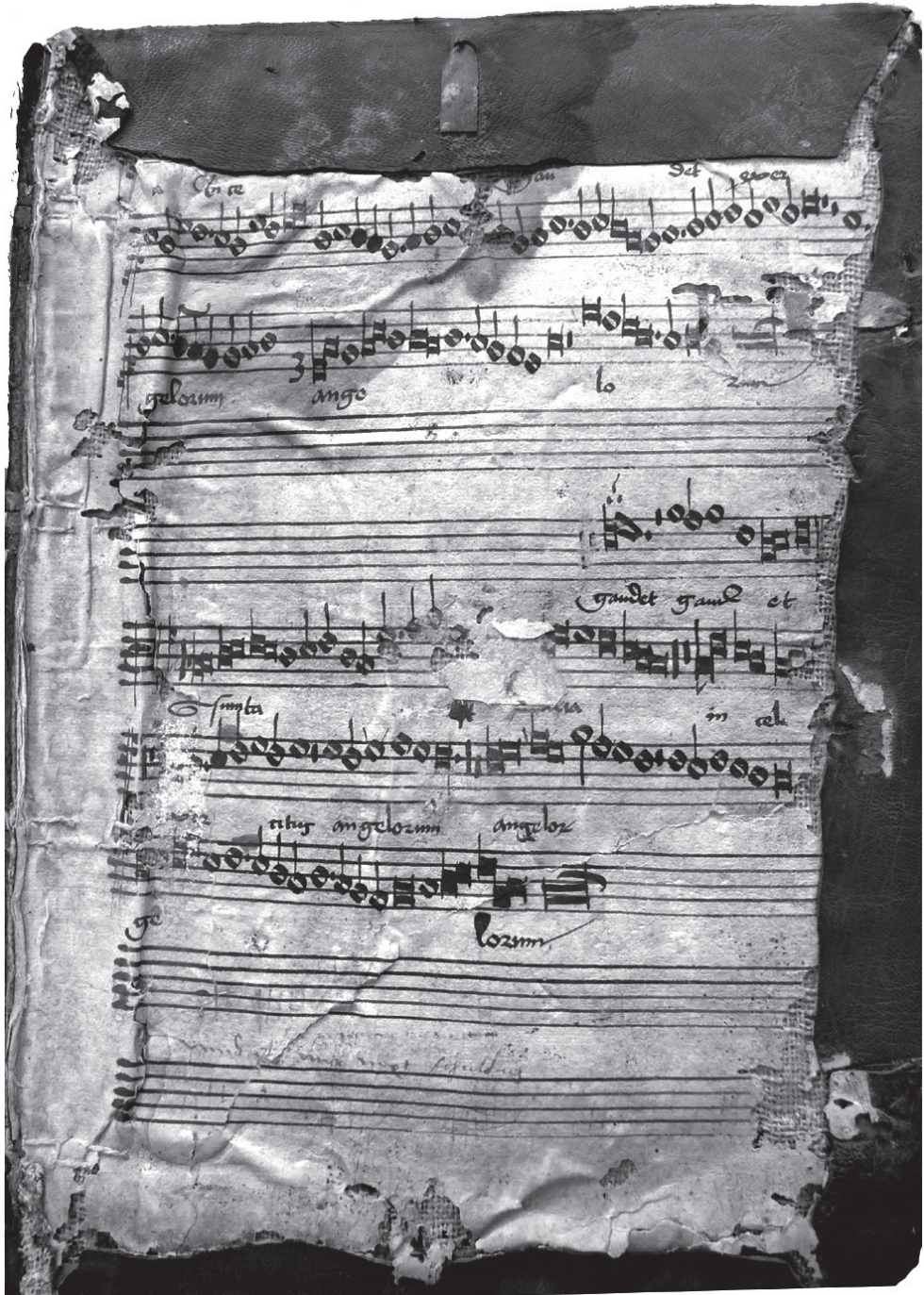

Obr. 4: Menzurálny fragment. Účtovná kniha mesta Spišská Nová Ves, 1514 - 1524 (C) Archív Spišská Nová Ves. Foto: Janka Petőczová 




5. Mapa Spiša, 1794.

(C) Spišský archív v Levoči. Foto: Štefan Péchy 


\section{Summary}

\section{Musical Topography of The Spiš/Zips Region With Regard to The EARLY Modern Period Cities}

The subject matter of the study covers research into regional musicology focusing on the history of music and musical culture of the Spiš/Zips region from the aspect of the musical topography. The research can be divided into two basic lines: demarcation of the music-topographic network inside the local habitations (towns, civitas, oppidum) and demarcation of the music-topographic network into the borders of the historical county of Spiš. Back in the Early Modern Period, in the county of Spiš, towns with an ethnically mixed, prevailingly Slovak-German population represent the basic topographic unit of our research. Towns that joined Luther's Reformation movement were the primary musical centres; in each of these towns, two institutions functioned as the driving force of the development of musical culture, namely the church and the school, with the cantor, the organist and the trumpeter working as professional musicians. The basic topographic network of the towns of Spiš is made up of localities in which the earliest preserved musical sources originated from the $16^{\text {th }}$ and the $17^{\text {th }}$ centuries. These towns are Levoča (Leutschau), Kežmarok (Kesmark), Lubica (Leibitz) and Vel'ká (Felka). More sources have been preserved from the period of the Late Baroque and Classicism; thus, the network of towns may be extended by Gelnica (Gölnitz), Kežmarok (Kesmark), Levoča (Leutschau), Lubica (Leibitz), Matejovce (Matzdorf), Podolínec (Pudlein), Spišská Belá (Zipser Bela), Spišská Kapitula (Zipser Kapitel), Spišská Nová Ves (Neudorf, Igló), Spišské Podhradie (Kirchdrauf, Warallia), Spišské Vlachy (Wallendorf), Smolnícka Huta (Schmölnitzhütte), Smolník (Schmölnitz), Švedlár (Schwedler).

A topical look at the music-topographic network of Spiš in the $16^{\text {th }}$ and $17^{\text {th }}$ centuries must take into equal account musical criteria (preserved primary sources of music and musical instruments) and non-musical criteria (secondary sources of music and sources of an archival character). Despite the relatively small number of localities on such a map of Spiš, the music-cultural centre of the region clearly appears to be its central part, in which a microregional area of increased contacts between the towns of Levoča - Spišské Podhradie - Spišské Vlachy - Spišská Nová Ves - Levoča was formed. Another locality consisted of towns in the upper parts of the Poprad basin, mainly of the five towns of Spišská Sobota, Matejovce, Velká, Poprad and Stráže pod Tatrami, where a musical culture of free towns, independent of feudal lords, was cultivated. The northern part of the Poprad basin was dominated by Kežmarok, a free royal town with an adjacent castle and Spišská Belá. On the Polish border, it was the towns long pledged to Poland: Hniezdne, Podolínec and Stará Lubovňa. In the southern parts of Spiš, vocal-instrumental polyphonic music was cultivated in Smolník. Very often, we have no information about the musical life of the smallest villages and settlements in Spiš, although it is certain that parishes existed in them and sacred singing by the cantor and the congregation was naturally present in their churches. Prospectively, research should be extended even to localities in which minimum information of a musical character has been preserved, just like in the small historical towns of Spišská Stará Ves, Huncovce, Žakovce, Iliašovce, Batizovce, Tvarožná, Krompachy, Švedlár, as well as to other types of localities (the Spiš Castle, the Lubovña Castle).

The specification of the music-topographic network of Spiš enables us to identify the locally and denominationally differentiated musical life of the towns of this region. Although such research is time-consuming and requires generalization, it may tackle the problem of the assessment of the unevenly preserved sources in the various localities of Spiš, as well as the problem of the integration of the history of music in Spiš into European music history. Music topography, as one of the basic methods of research on regions, provides a complex view of the history of music and musical culture in the changing geographical coordinates that are independent of political borders. 